\title{
EL LINAJE DE CRISTO A LA LUZ DEL "GIRO GENEALÓGICO” DEL SIGLO XV. LA RESPUESTA DE JUANA DE LA CRUZ
}

\author{
(1481-1534)
}

\author{
CHRIST'S LINEAGE IN LIGHT OF THE GENEALOGICAL TURN \\ OF THE 15TH CENTURY. THE RESPONSE OF JUANA DE LA CRUZ \\ (1481-1534)
}

\author{
ÁNGELA MUÑOZ FERNÁNDEZ \\ Universidad de Castilla La Mancha
}

El pueblo era el único que podía gloriarse de no tener probada sangre judaica, porque carecía de genealogías

(E. Benito Ruano, Los orígenes del problema converso, p. 58.)

\begin{abstract}
Resumen: Este trabajo se articula en torno al sermón de Santa Ana de El Conhorte de Juana de la Cruz. Su temática incide en imágenes de vida y generación y defiende el peso de las genealogías maternas. A partir de esta evidencia, se plantea su estudio como exponente del desarrollo en el mundo de los conventos femeninos de corrientes de opinión relacionadas con la Querella de las Mujeres que interactuaron con los principales focos del debate social y cultural de su época, debates que guardaron relación con el llamado "giro genealógico" que experimentaron las sociedades ibéricas en el siglo XV.
\end{abstract}

Palabras clave: escritura femenina; Juana de la Cruz; El Conhorte; Santa Ana; linaje de Cristo; Querella de las Mujeres; controversia judeoconversa; genealogías femeninas; siglo XV; Castilla.
Abstract: This research revolves around the sermon on Saint Anne in El Conhorte by Juana de la Cruz, focusing on imagery in the text about life and generation that supports the importance of maternal genealogies. Using this evidence as point of departure, this sermon is used as an example of shifting currents of opinion in female convents related to the Querelle des Femmes, currents of opinion that interacted with the main social and cultural debates of the period. These debates were closely related to the socalled "genealogical turn" which Iberian societies underwent in the 15 th century.

Keywords: women's writing; Juana de la Cruz; El Conhorte; Saint Anne; Jesus' Lineage; Querelle des Femmes; judeoconversa controversy; female genealogies; 15th century; Castile. 


\section{SUMARIO}

1. La cultura religiosa femenina hispana: el foco toledano.- 2. La genealogía como paradigma social y cultural en el siglo XV castellano.- 3. La genealogía humana de Cristo: el sermón de Santa Ana de Juana de la Cruz.- 4. Las genealogías femeninas en el marco del giro genealógico del siglo XV: consideraciones sobre el estatuto cultural del sermón de Santa Ana.- 5. Bibliografía citada.

\section{LA CULTURA RELIGIOSA FEMENINA HISPANA: EL FOCO TOLEDANO}

Los estudios dedicados a la cultura religiosa femenina en el ámbito hispano, enfocados desde el prisma de la historia de las mujeres y de las relaciones de género, surgieron a finales de los ochenta y a lo largo de los años noventa del pasado siglo, ya en contacto con la fértil línea de investigación que se consolidaba en el panorama historiográfico internacional. Estos estudios hubieron de afrontar, entre otras, dos cuestiones fundamentales. Una de ellas fue la no adecuación de los modelos hispanos a los modelos europeos, trasfondo del que surgía la problemática del particularismo hispano. La otra, que iba de la mano del estudio de las formas históricas que surgían del binomio mujeres y religión en el mosaico de los reinos peninsulares, hubo de acometer la cuestión del estatuto cultural de la expresiones religiosas desarrolladas en las tradiciones de los reinos ibéricos, campo que aún permanece abierto y en proceso de elaboración.

Las formas hispanas de espiritualidad femenina tuvieron durante la Baja Edad Media un escenario relevante en el entorno toledano, ámbito en el que se contextualiza el tema de estudio que se aborda en estas páginas. Diversos indicadores nos muestran la existencia de un foco cultural anclado a la ciudad del Tajo y a otros escenarios de distinto rango urbano que se acogían en la órbita jurisdiccional del arzobispado de Toledo ${ }^{1}$. En estos territorios, integrados en lo que se conoce como Castilla la Nueva, se desarrolló un rico mundo conventual femenino y un relevante movimiento de beatas y beaterios. De estos círculos religiosos surgieron figuras femeninas carismáticas dotadas de prestigio y eco social y formas de escritura que daban cuenta de sus experiencias.

La ausencia de nombres españoles en la relación de procesos de canonización instruidos por la Curia papal entre 1190 y 1431 llevó al historiador

1 Desde la disciplina de la Historia del Arte, el Toledo de mediados del siglo XV ha sido definido como un foco de novedades artísticas. Véase T. Pérez, El foco toledano y F. Pereda, La puerta de los Leones. En materia de santidad, un indicador relevante en el análisis de las agencias religiosas femeninas puede verse en A. Muñoz, Santidad Femenina; idem, Santas y Beatas, pp. 5-16 y 89 y ss. 
francés André Vauchez ${ }^{2}$ a señalar entre las conclusiones de su influyente estudio la no correspondencia de España, en particular Castilla, con la potencialidad creativa que caracterizó a otros países europeos en materia de generación de nuevos modelos de santidad. Los territorios hispánicos, concluía, esencialmente se conformaron con los cultos preexistentes. Sin embargo, estas apreciaciones piden ser matizadas si tomamos en consideración otros niveles de resolución del fenómeno de la santidad, aquellos que quedaron circunscritos a las escenas locales, sin dar nunca el salto a los estadios de reconocimiento sancionados por la curia papal. Una de estas escenas locales fue la ciudad de Toledo, donde la santidad femenina reconocida nos ofrece una tradición importante, si bien muestra una cronología tardía, pues no se documenta hasta el siglo XV, con un claro desfase temporal con respecto a otras áreas de la Europa cristiana, donde el fenómeno ya eclosiona entre los siglos XII y XIII.

En cuanto a la cronología, una regla de secuenciación temporal parece escalonar estas vidas de mujeres religiosas a lo largo del siglo $\mathrm{XV}^{3}$. Inicia la secuencia Mari García (1340-1426), la beata toledana de origen noble, sobrina del arzobispo de Toledo, que transitara libremente por los caminos de la reforma religiosa individual que prendió en las gentes de Castilla en el último tercio del siglo XIV, en plena crisis conciliar. Copartícipe del espíritu de reforma de los ermitaños jerónimos, a ellos vinculó su beaterio, fuera de todo vínculo canónico establecido. Diez años después de su muerte, un valioso testimonio evidencia cómo su fama de santidad había llegado a los círculos humanistas de la corte de Juan II y de su esposa, la reina doña María ${ }^{4}$.

Superada la primera mitad del siglo, Teresa López renovó la estela de santidad de su predecesora. No es mucho lo que sabemos de ella. Su experiencia de vida, según informa el cronista Alcocer, fue puesta por escrito en 1469 , muy posiblemente el año de su muerte, por Blas Ortiz, canónico y vicario de la iglesia de Toledo. Teresa López es posible que fuera una mujer de origen popular posicionada al margen de las órdenes religiosas, instituciones que difundían la fama de santidad de sus bienaventurados. Por ello resulta mucho más difícil reconstruir su memoria histórica.

En la década de los 70 gana notoriedad la figura de María la Pobre. Mujer de noble origen que pasó a lo largo de su vida por una variada gama de

\footnotetext{
2 A. Vauchez, La Sainteté. No sería hasta finales del siglo XVI y principios del siglo XVII cuando se impulsara la canonización de santos españoles, incluidas algunas de estas santas bajomedievales como Juana de la Cruz, la visionaria de Cubas de la Sagra. Hasta entonces, la santidad se resuelve en la escala de reconocimiento de las escenas locales, sancionada por las autoridades eclesiásticas correspondientes. Véase A. Muñoz, Santidad Femenina; idem, Santas y Beatas.

${ }^{3}$ Se resumen aquí los planteamientos recogidos en A. Muñoz, Santas y beatas, pp. 89 y ss.

${ }^{4}$ D. de Valera, Tratado de defensa, p. 65.
} 
estados religiosos. De su inicial dedicación a la pobreza radical y a la mendicidad a favor de los pobres pasó a la asistencia a enfermos y desheredados, con una entrega que superaba los límites previstos por el sistema hospitalario de su época. Conoció también la vida contemplativa durante un periodo de reclusión en la iglesia mayor de Toledo, experiencia que le dio acceso a los dones visionarios. Sus visiones y profecías lograron eco en el ambiente providencialista que espoleó el reinado de los Reyes Católicos, ya que, a decir de Yanguas, incidían en asuntos de gran calado político y religioso, como fueron la conquista de Granada o el establecimiento de la Inquisición. Nos dicen los cronistas de la orden clarisa, familia religiosa en la que ingresó y permaneció María la Pobre en el último tramo de su vida, pues fundó el convento de Santa Isabel de Toledo, que estos dones visionarios le depararon la buena consideración de los monarcas castellanos Isabel y Fernando y de los clérigos de la iglesia toledana.

Esta relación la completa en la penúltima década del siglo XV, María de Ajofrín otra beata perteneciente a la comunidad que fundara décadas atrás Mari García, exponente de un modelo de santidad místico-visionaria direccionado en frentes diversos, uno de ellos la crítica radical al clero secular de la ciudad con el consiguiente llamado a su reforma interior, en la línea críticovisionaria que mantuvieron Brígida de Suecia y Catalina de Siena durante el cisma de Aviñón ${ }^{5}$.

De todas las mencionadas, la figura más notable y de mayor proyección fue, sin duda, Juana de la Cruz, (1481-1534), la religiosa terciaria franciscana, natural de la localidad toledana de Azaña, que profesó en el convento de terciarias franciscanas de Cubas de la Sagra, una pequeña localidad situada al sur de la actual comunidad de Madrid. Juana se convirtió en exponente de un nuevo horizonte de planteamientos y estímulos, de genuinas elaboraciones que respondían al clima social, cultural político y religioso de su tiempo. Nos llega su voz a través del El Conhorte, un original y extenso escrito al que tendremos ocasión de volver en las páginas siguientes.

Este elenco de figuras induce a pensar que durante el siglo XV el área de Toledo estuvo a la vanguardia peninsular en la reproducción de modelos europeos de santidad femenina. Estos casos constituyen un campo de observación privilegiado, pues sus primeros exponentes -véase el caso de Mari García- nos permiten retrotraer este tipo de fenómenos casi un siglo respecto a los primeros años del siglo XVI, fechas que se han venido tomando como el hito referencial en la incorporación y difusión de este tipo de fenomenología

${ }^{5}$ Sobre María de Ajofrín, véase R. Surtz, Writing Women, pp. 68-84; y A. Muñoz, Santidad femenina, centrado en el estudio monográfico de esta figura. 
religiosa en la península Ibérica, un hecho que se ha querido ver asociado a la empresa de traducción y edición de algunos de los más señeros textos de la cultura religiosa femenina italiana y renana que impulsó el propio Cardenal Cisneros ${ }^{6}$.

De este mundo surgieron las primeras codificaciones hagiográficas que nos informan de las experiencias de vida de estas mujeres y, lo que parece aún más relevante, las primeras expresiones de escritura religiosa de autoría femenina. Constituidas en relevantes fuentes históricas, unas y otras formas de escritura nos permiten perfilar modelos, establecer comparativas, afinar más en el análisis de los particularismos que ofrecen estas expresiones de cultura religiosa, y ahondar en las interacciones culturales que mantuvieron con otros procesos de su contexto histórico.

Los patrones de contacto con la cultura escrita que se dieron en este foco de cultura religiosa femenina revelan el predominio del clero como agente de escritura. Es habitualmente un fraile de la orden a la que se vincula la santa en cuestión, en algunos casos un cura secular, la figura que acomete la empresa de poner por escrito las experiencias de vida de aquella cuya fama de santidad se desea dar a conocer y perpetuar en el tiempo. No se excluye, sin embargo, la participación femenina. Pero la capacidad de producción textual de las beatas parece quedar reducida a los patrones de escritura por mandato y a la producción epistolar, una práctica que se sanciona con tópicos de intervención sobrenatural. Es el caso de esas cartas milagrosamente escritas por María de Ajofrín, que superan las pruebas del fuego y el agua y que pasan a convertirse en objetos sagrados con poderes taumatúrgicos.

Una magnífica excepción a la regla nos la ofrece el beaterio-convento de Santa María de Cubas de la Sagra, institución que actuó como auténtica comunidad textual donde las propias terciarias fueron agentes de escritura. Aquí ubicamos la figura imponente y compleja de Juana de la Cruz. María Evangelista - nótese el significado que se inscribe en este nombre- redactó una biografía de Juana de la Cruz, y una o dos monjas de la comunidad pusieron por escrito los sermones que pronunciaba ante público y bajo estado de arrobo místico ${ }^{7}$. Sólo uno de ellos, el que sirve de colofón al Conhorte, aparece da-

\footnotetext{
${ }^{6}$ De obligada referencia son las aportaciones de P. Sainz Rodríguez, La siembra mística; así como los trabajos de V. Beltrán centrados en María de Santo Domingo, incluidos en la recopilación, Miscelánea Beltrán Heredia, pp. 335-405, 447-461, 519-671. Más reciente, J. Bilinkoff, Charisma and Controversy. De María de Santo Domingo y su relación con la tipología de las santas vivas, ya dio noticias G. Zarri en su Le Sante vive.

${ }^{7}$ A la tradición de este beaterio y posterior monasterio, pertenece el siguiente corpus textual el Conhorte, Biblioteca de El Escorial, Ms. J-II-18; Vida y Fin de la Bienaventurada virgen Sancta Juana de la Cruz, Escorial, Ms. K-II-13 y Libro de la casa y monasterio de Nuestra Señora de la Cruz, Biblioteca Nacional (Madrid), Ms. 9661. Hasta ahora, la monografía de referencia es la de R. Surtz, The Guitar of God; Una edición del Conhorte, I. García, El Con-
} 
tado en 1509, si bien en el estado actual de nuestros conocimientos se piensa que el proceso de escritura de este singular sermonario se dilató por trece años. Nacía así el Conhorte, uno de los textos más originales y significativos de la cultura religiosa europea e hispana de su tiempo, un texto que se enraíza en contexto político-religioso cisneriano y que responde a las problemáticas y expectativas de su tiempo.

Del fondo de sermones contenidos en el Conhorte de Juana de la Cruz, el dedicado a Santa Ana, la madre de María, constituye una pieza singular sobre la que la religiosa terciaria vuelca sutiles argumentos que requieren un meticuloso análisis, ya que nos acercan, desde una mirada femenina, a la problemática del linaje y la cultura genealógica que eclosiona en Castilla en el contexto socio-político y cultural del tardo Medievo y la alta Edad Moderna. En esta pieza textual centraremos nuestra atención en este trabajo, que se articulará en cuatro momentos que parten de los contextos amplios para llegar a los concretos. En la confluencia de unos y otros se abordará estudio de este sermón.

Con este estudio se pretende también abordar la problemática de la traducción cultural del texto, cuestión que pasa ineludiblemente por la identificación de los nexos contextuales que éste mantiene con otras problemáticas sociales y con sus derivas textuales. Vuelvo sobre un documento ya estudiado en anteriores ocasiones ${ }^{8}$ para someterlo a un análisis ampliado en la vertiente puramente textual, la que afecta al contenido, al léxico y a los énfasis que introduce. He renovado este análisis en su dimensión contextual, lo que nos permitirá redimensionar el texto en sus pasajes más comprometidos, a la luz de los elementos que lo ligan a las principales problemáticas y frentes de debate social de su época. Así, identificando con precisión sus contenidos y estrategias narrativas, detectando redes de sentido y líneas de conexión con otras problemáticas, enfocando desde otras luces el propio estatuto cultural del texto, se pretende ampliar nuestra comprensión de las culturas religiosas femeninas del momento, y resituar la agencia femenina en el marco de los procesos culturales que recorren el reino de Castilla durante el siglo XV.

horte. Se suman los estudios que sobre esta figuran han realizado J.A. Boon, Christ at Heavenly Play; eadem, Mother Juana de la Cruz; eadem, The Glory of the Virgin; M. del Mar Graña, El cuerpo femenino; eadem, La feminidad de Jesucristo, eadem, Teólogas de una nueva memoria; A. Muñoz, La nuova legge.

8 Se encontrará un primer estudio en A. Muñoz, La reescritura, donde se analizaba este sermón junto a los contenidos relacionados con Santa Ana que Isabel de Villena dejó plasmados en su Vitae Christi. 


\section{LA GENEALOGÍA COMO PARADIGMA SOCIAL Y CULTURAL EN EL SIGLO XV CASTELLANO}

Los usos que se dieron a la voz "linaje" en el lenguaje del siglo XV resultan muy significativos. A la acepción propia sobre la familia y parentesco, a la línea de ascendencia o descendencia en torno a la cual se agrupaban y organizaban los grupos familiares, se sumaron otros muchos. Se constata como sinónimo de pueblo o nación y con la acepción más vaga de grupo social de contornos más o menos delimitados. En la Sentencia-Estatuto de Pero Sarmiento, la expresión conversos del linaje de los judios encuentra su correlato en el colectivo de ciudadanos de los que partía la propuesta, quienes a sí mismos se nombraban cristianos viejos lindos ${ }^{9}$. Un acercamiento a la semántica histórica de la voz lindo contribuye a confirmar el juego de polaridades que se establecía porque, si ya desde el siglo de Oro esta palabra había tomado el sentido vago de elogio, tan vasto y comprensivo como la palabra bueno, en los siglos XIV y XV, por una traslación de sentido, fue corriente que significara "auténtico", "puro" e incluso, a veces, "noble"10. A mediados del siglo XV, los lenguajes de la raza, de la religión hegemónica y de la nobleza interactuaban componiendo constelaciones de sentido en una lógica transferencial de enunciados que se impondría, cursando en nuevos itinerarios de operatividad política, social y cultural.

El interés por las nociones de linaje y genealogía fue originariamente formalizado en el marco de las realezas y de las noblezas medievales, tanto europeas como peninsulares ${ }^{11}$. Esta cuestión por la que también mostraron ávido interés las oligarquías urbanas, que vieron en estas estructuras del parentesco un instrumento de individuación y diferenciación social, de representación y formalización del poder, se proyectaba ahora en amplios colectivos ciudadanos y populares. Los sucesos toledanos de 1449, hoy bien estudiados en sus desarrollos factuales ${ }^{12}$, contexto en el que nació la SentenciaEstatuto de Pedro Sarmiento, se dejan leer como la apertura de un expediente ampliación de las bases sociales sobre las que se proyectó la preocupación por la ascendencia y el linaje, en tanto que lugar de procedencia y pertenencia de los individuos. Emergía esta proyección con nuevas funcionalidades polí-

9 E. Benito Ruano, Los orígenes, p. 86.

${ }_{10}$ S. de Covarrubias, Tesoro de la lengua, voz: Lindo-Limpio.

${ }_{11}$ G. Spiegel, Genealogía; L. Genicot, Les généalogies; J. Mattoso, Os livros. Véase también el monográfico publicado por la revista "e-Spania", Légitimation et lignage y J.R. Prieto Lasa, La genealogía de los Haro.

${ }^{12}$ Es muy abundante la bibliografía generada en torno a este episodio y sus consecuencias. Además de la bibliografía referenciada más adelante, véase E. Benito Ruano, Toledo en el siglo $X V$ y más recientemente, B. Netanyahu, Los orígenes, pp. 143-645. 
ticas e ideológicas de signo excluyente, pues esta forma de socialización de la cultura genealógica, por la que tanto hicieron las prácticas inquisitoriales, sirvió para imponer una marca de ascendencia que iría calando paulatinamente en los selectivos procesos de ingreso de las instituciones que dominaron en la España Moderna.

La Sentencia, documento significativo en sí mismo a la luz de los términos recogidos, prendió la llama de una acalorada polémica entre quienes defendían o atacaban tan tajante decisión. Se originó de esta forma lo que Albert Sicroff denominó una guerra de escritos ${ }^{13}$. Algunos de los más significativos de ellos vieron la luz en el bienio de 1449-1450.

Alonso de Cartagena fue el primero en tomar la pluma para redactar una obra en defensa de la unidad del pueblo Cristiano en la que se integraban tanto los cristianos viejos como los de origen converso. Hizo uso de la retórica del linaje como vía de integración del colectivo converso. El linaje como línea genealógica permitía a estos tratadistas realizar unos recorridos ascendentes y descendentes cuyos hitos quedaban cifrados en los patriarcas. Esta matriz retórica de extraordinario interés para las cuestiones que aquí tratamos, tiene en la obra de Alonso de Cartagena expresiones modélicas.

Para Alonso de Cartagena la Biblia hebrea, depositaria de la Antigua Ley, la ley de los Patriarcas, permitía articular la idea integradora del humanal linaje que surgía de un ancestro común, condición de posibilidad para la existencia de un marco identitario compartido. Alonso de Cartagena halló en el Génesis argumentos sólidos para la defensa de la integración de los cristianos de origen converso en la casa común de la Iglesia, borrando las marcas de origen de la carne. En ello jugaba un destacado papel Adán, sobre el que argumentaba:

Un solo Adán fue creado como dice la escritura: hagamos el hombre a nuestra imagen y semejanza. No dijo a los hombres, sino al hombre, para manifestar desde el mismo principio que pensaba en la unidad de los hombres y que la diferencia entre ellos, basada en la propagación de la carne, la aborrecía. Aunque el que lo piense detenidamente concluya diciendo: los creó macho y hembra.

13 A. Sicroff, Los estatutos, nombró como "guerra de escritos" el fenómeno mediante el cual se respondió con la pluma a la violencia popular desatada en este marco conflictivo. En esta línea se expresa también E. Benito Ruano, Los orígenes. Algunos de los ejemplos más significativos de este cuerpo de escritos, dejando al margen los tratados de los más destacados autores (el cardenal Juan de Torquemada, Alonso de Cartagena obispo de Burgos, fray Lope de Barrientos, obispo de Cuenca, o Ferrán Díaz de Toledo, relator del Consejo Real), centrados en el marco de la ciudad de Toledo, fueron la propia Sentencia-Estatuto de Pero Sarmiento o el Memorial del Bachiller Marquillos de Mazabroz, ambos textos editados en E. Benito Ruano, Los orígenes; R. Gonzálvez, El Bachiller Palma. Véase ahora: E. Pastore, Una herejía; L. Giordano, Apologetas de la fe. 
Y la verdad lo dice: “¿no habéis leído por qué el que los hizo desde el principio, los hizo macho y hembra?"

Esto ha de entenderse, conforme a la explicación interlineal, no a la vez en el tiempo, sino en la presciencia divina, como la misma Escritura puso en claro cuando al exponer con más detalle el orden de la creación, dice: "formó, pues, el señor Dios al hombre del polvo de la tierra y le inspiró en el rostro aliento de vida y fue así el hombre animado". Y poco después añadió: "no es bueno que el hombre esté solo. Hagámosle una ayuda semejante a él. Y así hizo caer sobre Adán un sueño profundo y tomó una de sus costillas cerrando en su lugar con carne, y de la costilla que del hombre tomara formó el señor Dios a la mujer". Por lo tanto no fueron hechos dos o más al mismo tiempo, sino que en el principio sólo fue creado Adán, y a él ya formado se le añadió Eva, y se hicieron dos en una sola carne, de tal manera que de la dualidad no se juzgase divididas la unidad de la unión y armonía de los corazones y aún la de los cuerpos ${ }^{14}$.

Así, con el relato del Génesis y la creación de la primera pareja humana, comenzaba Alonso de Cartagena su Defensorium Unitatis Christianae, un escrito elaborado en pleno fragor de la polémica que habían desatado los acontecimientos toledanos de 1449. Capitalizaba para su causa el argumento del origen común del género humano en la pareja primordial. Evidenciaba de esta forma la trascendencia que tenía la estructura simbólica de los orígenes en cualquier proceso de legitimación. Aquí asentaba sus argumentos acerca de la unidad de la cristiandad y su defensa de los cristianos de ascendencia judía.

Sus razonamientos y argumentos nos dan pistas sobre otra cuestión compleja, la relevancia de las mujeres en este proceso de legitimación construido sobre una escala genealógica que ascendía por los patriarcas hasta concluir en Adán como ancestro común. Es necesario introducirnos en la densa tradición exegética que se ha desarrollado sobre los relatos del Génesis sobre creación de la primera pareja ${ }^{15}$ para apreciar la carga ideológica que subyace en los argumentos elaborados por el obispo y humanista burgalés de origen converso. Al cimentar sus razonamientos en los elementos que ofrece el relato de Gen. 2, 7-25, donde se recoge el nacimiento de Eva a partir de la costilla de Adán, Alonso de Cartagena defendía un régimen de la creación de la primera

${ }^{14}$ Cito por la edición de G. Verdín, Alonso de Cartagena, primera parte, cap. I, p. 107. La cursiva es mía.

15 J. Cruz, Finalidad femenina, pp. 513-540. Para los planteamientos estructurales del tema en el marco de la Querella hispana del XV, véase Á. Muñoz, Mujeres y religión, pp. 715-742. Contempla el tema atendiendo a los argumentos desarrollados por los diversos autores que aborda R. Archer, La cuestión odiosa. También A.Vargas, La Querella de las Mujeres. 
pareja humana caracterizado por diferencias de tiempo, espacio y materia ${ }^{16}$, diferencias continuamente alegadas en la tradición exegética como prueba de la precedencia del varón sobre la mujer.

La búsqueda de un ancestro común parece ir requerida del rechazo de la dualidad inherente a la primera pareja como matriz originaria de la especie humana y, al enfocar específicamente en Adán, la figura de Eva retrocede significativamente a zonas de penumbra. La diferencia sexual queda velada realzándose el sexo masculino. Indirectamente, también rinde cuentas a esta lógica el argumento de la fusión amorosa del hombre y la mujer en una sola carne. Por otro lado, la propagación de la humanidad según el régimen de la carne siembra diferencias sociales no queridas por Dios. Por ello, la Iglesia ofrece un nuevo marco de integración en el que los sacramentos borran toda huella de impureza. La mácula originaria era limpiada por el bautismo, dejando en la sombra el significativo enunciado "nacido de mujer".

El nacimiento se convierte en una pega, es una circunstancia que encumbra o lastra socialmente. Este hecho, ligado a los cambios que iban operando en la base del sistema social, donde se verifican transformaciones como el avance del mayorazgo, un sistema de estructuración del linaje y de la herencia que priorizaba masculinidad y primogenitura, nos abre las puertas a un panorama negativo para las mujeres, ya que desde su posición de madres, esposas e hijas también se integran en estas estructuras del linaje.

En este orden de cosas, Alonso de Cartagena minimiza el valor de las prerrogativas del nacimiento frente a la virtud individual. Un vector polémico muy parecido al que se planteó en el debate sobre la nobleza y la caballería, debate en el que también intervino este obispo burgalés de origen converso ${ }^{17}$. Así expone este conocido argumento en su Defensorium unitatis,

de manera clara hizo ver que en aquel tiempo ninguna gente era preferida a otra por prerrogativa de nacimiento, sino que todos estaban incluidos bajo unidad de un solo pueblo y de una sola gente, y que todos habían de ser distinguidos por la virtud o el vicio de las personas, no por diferencia de origen carnal ${ }^{18}$.

Frente a la prerrogativa del nacimiento se aboga por la virtud individual, la que confiere calidad de los individuos. La propagación carnal, base de

${ }^{16}$ Un modelo más igualitario de la creación es el explicitado en Gen 1, 26-27.

17 Este ha sido un tópico bien identificado y abordado por la historiografía centrada en el campo de la nobleza y de la caballería, como referencia básica remitimos a J. Rodríguez Velasco, El debate. Su reflejo en los nobiliarios de finales del siglo XV puede seguirse en F. Mexía, Nobiliario Vero.

${ }^{18}$ G. Verdín, Alonso de Cartagena, p 109. 
la reproducción de los sistemas familiares suponía un obstáculo para la integración de los judeoconversos. De ahí el énfasis puesto en la fe común, en los nuevos contornos comunitarios que la catolicidad ofrece; de ahí la importancia conferida a los sacramentos del bautismo y de la comunión como ritos integradores, generadores de nuevas formas de parentesco. Estos ritos sacramentales se nutren de metáforas femeninas en el discurso de Alonso de Cartagena, para quien los obispos y prelados eran las "parteras" del nuevo nacimiento:

¿Quién más desvergonzadamente desprecia el fruto del parto de su madre que aquél que como otro farallón intenta matar, y sin culpa alguna por parte de ellos, a los nacidos de las entrañas de la Iglesia, cuya imagen representa Sara, y a los limpios desde el vientre de la fuente bautismal por medio del sacerdote como por comadrona? Porqué no es menos el quitar la fama y acusar de infamia al inocente que el dar la muerte corporal.

(...) Por la palabra parteras es justo que se entienda en primer lugar los romanos pontífices y después cuantos en la Iglesia tienen las llaves de Dios para atar y desligar, para abrir y cerrar. Estos pues, poseen el arte de la ciencia de ejercer espiritualmente el oficio de partera cuando litúrgicamente, en representación de la Iglesia, sacan del vientre de la madre a los fieles que se bautizan, de tal manera que así como a los que yacen dentro de la oscuri-dad de las entrañas de la carne se les trae hacia esta luz temporal por mano de la partera, así los ciegos por las tinieblas de la infidelidad, por medio de la lengua del que administra el bautismo al proferir las palabras apropiadas, se les conduce como por mano de partera a la luz verdadera que ilumina a todo hombre que viene de este mundo, al sol verdadero de justicia, Cristo nuestro Dios; y a los guiados se les alimenta espiritualmente con algunos sacramentos.

Mas sigamos adelante, $\vdots$ acaso no desprecia el fruto de su madre el que no se avergüenza de desdeñar a su hermano nacido del fruto de la Iglesia?19.

Los argumentos de Alonso de Cartagena lo muestran claramente, el nacimiento es una categoría implícita en las nuevas dialécticas de integración y exclusión que irrumpen con fuerza en estos momentos. Constituye un problema a resolver:

De manera manifiesta escarnece al padre el que menosprecia al hijo, porque recae sobre el padre el honor que se da al hijo. ¿No es evidente, pues, que de manera vergonzosa menosprecia a los muy honrados y antiguos padres, más bien a los patriarcas Abrahan,

19 G. Verdín, Alonso de Cartagena, pp. 376-379. 
Isaac y Jacob, quien juzga despreciables, por más fieles y católicos que sean, a los que por la procreación de la carne descienden de ellos, por el mero hecho de que descienden de su pueblo?

Mas ¿qué digo de menosprecio de patriarcas, cuando abiertamente menosprecia a nuestro señor Jesucristo, príncipe y señor de los patriarcas, quien con atrevimiento temerario trata de reprochar aquella sangre de la cual Él se dignó descender carnalmente y consecuentemente denigra, y no poco, el honor de la bienaventurada e Inmaculada María, su madre, así como el de los santos varones que a través de los tiempos descienden de aquellos padres?20.

A estos significativos elementos se suma la generalización de unas narrativas genealógicas fuertemente patriarcalizadas. Con frecuencia, Alonso de Cartagena va desgranando en sus argumentaciones los hitos que componen la genealogía del pueblo cristiano que no son otros que los patriarcas de la Vieja Ley, esa secuencia de figuras masculinas que sellan los distintos pactos que Dios realizó con su pueblo.

Esta elaborada argumentación de la integración eclesial de los individuos por fuerza afectaba a la posición de las madres y devaluaba la presencia femenina en la estructura simbólica de los orígenes, una tendencia que también sancionaba la cultura emergente de los nobiliarios ${ }^{21}$.

La ausencia de las madres en estas genealogías, exceptuada la Virgen María, que se constituía en excepción, contrasta con estas otras cuestiones capitales, el peso real de las madres en la vida común, en la producción de los cuerpos y en la crianza de las criaturas, la autoridad que les es reconocida y debida. No en vano, esta sintomática cuestión se reactiva en los primeros tratados de defensa de las mujeres que se escribieron en la década de los cuarenta del siglo XV, cuyos autores polemizaron con las teorías aristotélicas de la generación ya entonces en curso de generalización en los ambientes eruditos del humanismo cuatrocentista ${ }^{22}$.

A la luz de todos estos indicios y tendencias, se pone de manifiesto cómo la variable sexo-género, se vio afectada en los procesos sociales y culturales que estaban en proceso de estructuración en la coyuntura de mediados del siglo XV. En este marco histórico arrancaban con fuerza en Castilla tres importantes debates sociales que generaron un significativo cuerpo de escritos: la Querella de las Mujeres, la polémica judeoconversa y debate sobre la

20 Ibidem

${ }^{21}$ A. Sicroff, Los estatutos de limpieza de sangre, p. 67, ya señaló la importancia que tuvieron entre estos apologetas de la fe cristiana las metáforas biológicas, sin estudiar el subtexto de género implícito en ellas. Sobre este tema véase Á. Muñoz, Las parteras.

22 Véase Á. Muñoz, María y el marco teológico. 
nobleza y caballería. En esta encrucijada que se prolonga a lo largo del siglo XV y el primer tercio del siglo XVI, situamos nuestro análisis del sermón de Santa Ana de Juana de la Cruz.

\section{LA GENEALOGIA HUMANA DE CRISTO:}

EL SERMÓN DE SANTA ANA DE JUANA DE LA CRUZ

El modo o modos de especulación de las imágenes de familia y linaje en la teología política del tardo Medievo es cuestión que merece una mirada atenta. La razón es obvia, estos debates resultaron ser las arenas fértiles sobre las que se proyectaron representaciones, creencias y vivencias, emanadas de los diferentes agentes sociales que, imbuidos de posiciones e intereses distintos, conformaban el cuerpo social.

El auge político, social y discursivo que experimentaron las cuestiones del linaje y los orígenes familiares en la sociedad castellana del siglo XV, particularmente en su segunda mitad, coincidió con el proceso de expansión de las narrativas pasionarias que por doquier difundían imágenes de nacimiento y de cuidado materno. Las narrativas textuales e iconográficas de la vida, pasión y muerte de Cristo, con su énfasis en la Encarnación y nacimiento del Hijo de Dios y en la maternidad de María -escenarios de exclusivo protagonismo femenino-, eclosionaron con especial fuerza durante todo el siglo XV. En la Península Ibérica, esta eclosión narrativa alcanza su más intensa configuración a lo largo del último tercio de la centuria ${ }^{23}$.

El desarrollo de la cristología y las devociones pasionarias, no hay duda, constituye uno de los fenómenos culturales más significativos de la Baja Edad Media. El cumplimiento del plan de la Redención ponía en el centro de la cultura común, tanto erudita y como iletrada, el misterio de la Encarnación, proceso por el cual el hijo de Dios tomó carne humana. Con ello se ponía en evidencia la cuestión del humanal linaje de Cristo, asunto que hacía aflorar a un primer plano la figura de María.

La Encarnación de Cristo en el vientre de María confirió al Hijo de Dios la condición de nacido de mujer, lo que abrió un frente de figuración y de especulación teológica de amplio calado social y cultural. El reconocimiento de Cristo como el Mesías esperado llegó a ser un punto de fricción entre ju-

${ }^{23}$ Entre la mucha bibliografía sobre el tema pasionario remitimos a P.M. Cátedra, Poesía de Pasión; un completo estudio con bibliografía actualizada en C. Robinson, The Passion; sobre la Pasión en el universo textual de los conventos de dominicas del último tercio del siglo $\mathrm{XV}$, véanse las observaciones de Á. Muñoz, Memorias del Coro; hemos de referir aquí también el importante conjunto bibliográfico que se ha desarrollado en torno a la Vita Christi de Isabel de Villena. 
díos y cristianos. Por ello, el tema se revistió de ciertos tintes polémicos que rendían cuentas a los procesos de confrontación interreligiosa que se fueron anudando con el conflicto judeoconverso. Así pues, la genealogía humana de Cristo, judío por nacimiento -es decir según el régimen de la carne- e iniciador de una nueva etapa en la historia de la humanidad centrada en la Nueva Alianza, -fundamento de la religión cristiana-, se hizo materia sensible en el marco de las relaciones interreligiosas del siglo XV. La genealogía se convierte por caminos paralelos y entrelazados en una cuestión de gran calado social y religioso en el contexto castellano de finales del Medievo.

La cultura religiosa medieval generó en torno a la historia de la Redención humana un corpus de imágenes ligadas a la familia que adoptó diversos patrones de representación visual. A decir de algunos estudiosos del tema, estas formas dieron cauce de representación al misterio inmaculista antes de que éste generara sus propios modelos visuales, algo que no se consolidó hasta avanzado el siglo XVI. Una de ellas fue el Árbol de Jesé, patrón por antonomasia de la representación genealógica humana de Cristo. La genealogía de Cristo aquí es presentada por una combinación de Mt. 1,16 y la profecía de Isaías 11,1 e Isaías 11,10. El modelo iconográfico recoge un árbol o rama que nace del cuerpo de Jesé, en ocasiones de su pecho, cuyos brazos soportan un número variable de figuras del Antiguo Testamento. Reyes y profetas van enlazando una línea que parte de Jesé y a través de la Virgen culmina en Cristo. La interpretación de Tertuliano veía ya a María como la rama que surge de la raíz de Isaías y a Cristo como la flor y el fruto. Las primeras genealogías mesiánicas iluminaron manuscritos de los siglos XI. Pero será en el siglo XII cuando esta imagen se desarrolle siguiendo un camino paralelo a la expansión de la iconografía mariana. En el siglo XIII la madre con el hijo reemplaza a Cristo como figura superior del árbol de Jesé. Durante el siglo XV se generalizarían estas imágenes por toda Europa con diversas variantes ${ }^{24}$.

Consecuentemente, sobre el arquetipo del árbol se especularían propuestas diversas relacionadas con este régimen genealógico de representación vertical de largo trazado en el que domina la patrilinealidad. El árbol genealógico constituye una figura de representación de amplia proyección, versátil en sus aplicaciones sociales e institucionales, que condensa expresiones acabadas de memoria histórica ${ }^{25}$.

${ }^{24}$ Son numerosos los estudios que se han acercado a este motivo desde el clásico de A. Watson, The Early; véanse, además, A. Domínguez, Iconografía evangélica; idem, Del árbol de Jessé; idem, La Virgen, rama y raíz. Otras representaciones en M. Poza, Santo Domingo de la Calzada; E. Valdez, Visiones y profecía; M. D. Teijeira, La iconografía del árbol; A. Coomarasway, The Tree of Jesse; E. Simmons Greenhill, The Child in the Tree.

${ }^{25}$ Dos referencias fundamentales sobre el tema, C. Klapisch-Zuber, L'Ombre des ancêtres; y A. Guerrau, L'Arbre de Jesé. 
Hubo otra forma de representación de la familia de Cristo que ponía el foco de atención en Santa Ana y la santa parentela. Este modelo, de claro protagonismo femenino, modifica el anterior por doble partida: acortando el trazado vertical de la sucesión generacional y modificando los sujetos que integran la estructura genealógica. Aquí sólo se representan tres figuras, evidenciándose ante todo la genealogía materna de Cristo con una santa Ana que acoge, sea en sus brazos o en el regazo, a una María que porta a su hijo, Jesús. Este modelo de representación señala una fracción generacional operativa, lo que podríamos denominar un vínculo intergeneracional $v^{1} \mathrm{vo}^{26}$. La relación abuelos-nietos es común, no así la de bisabuelos y biznietos. Este marco de relaciones intergeneracionales ha sido una de las vías más eficaces de transmisión oral de saberes y de experiencias ligadas al vivir ${ }^{27}$. Ligadas a esta Ana trinitaria se dieron otras formas de representación de la familia de Cristo, una de las más difundidas fue la llamada santa parentela. Pero la incidencia de este modelo de representación en la cultura visual hispana del cuatrocientos fue menor.

En el primer tercio del siglo XVI se registra un cambio significativo. La representación de Santa Ana Trinitaria cuyo eje vertical enfatizaba claramente una matriz genealógica femenina, tendió a ser desplazada por una representación de Santa Ana, la Virgen María y el Niño inmersos en una escena de vida cotidiana en la que predomina la línea horizontal. Se velaba el referente genealógico que parece propiciar el modelo de la Ana Triple. Ambas fórmulas las encontramos peculiarmente extendidas en la cultura visual hispana de los siglos XV y XVI, en altares, retablos y capillas, en escultura, pintura y en grabados ${ }^{28}$.

Dadas las potencialidades simbólicas que subyacen a estas formas de representación de Cristo, los cambios visuales señalados pueden ser tomados como síntomas significativos de realidades vivas en las sociedades de los reinos hispánicos. Las plasmaron en sus escritos dos escritoras hispanas de finales del XV y de las primeras décadas del siglo XVI, Isabel de Villena y Juana de la Cruz. Ambas autoras nos dejan ver la intensa actividad de recreación cultural que se desarrolló en los espacios religiosos y conventuales femeninos hispanos. En ellos se alentó un intenso proceso de recepción de las culturas pasionarias, que enfocaban, y este es uno de sus rasgos más genuinos, en el protagonismo de la madre y la abuela de Cristo ${ }^{29}$.

${ }^{26}$ Hacía falta cuatro generaciones, el salto de la tríada generacional común, para consolidar nobleza y para superar la mácula de los orígenes conversos. Cuatro, establece F. Mexía para consolidar nobleza genealógica.

27 El motivo de Santa Ana estuvo asociado también al libro, véase n. 29.

28 Sobre Santa Ana, K. Ashley, P. Sheingorn (eds.), Interpreting; E. Ruíz-Gálvez, Religión de la mère; idem, Maternité, Sainteté; V. Nixon, Mary`s Mother o F. Pereda, Mencía de Mendoza.

29 Véase Á. Muñoz, La reescritura. 
Dejando a un lado a María, una figura de enorme peso en el universo religioso de nuestra visionaria, pocas mujeres se asoman al sermonario de Juana de la Cruz como protagonistas. Santa Ana, María Magdalena, (sermón 38), y Santa Clara (sermón 45) son la excepción a esta regla. El sermón de Santa Ana, el que ahora nos interesa, viene registrado en el Conhorte con el número 39 y el título, Que trata de las excelencias y vida y acabamiento de la gloriosa Santa Ana. Una atenta lectura nos permite identificar una estructura interna tripartita que responde a tres marcos situacionales bien diferenciados. El primero se centra en la historia de la concepción de María en el vientre de Ana. El segundo en las relaciones de intimidad de Ana, la abuela, con su nieto, Jesús. Y el tercero en las fiestas que se celebran en el Cielo en honor de la abuela de $\mathrm{Cristo}^{30}$.

El primer escenario al que nos acerca el sermón 39 nos lleva a las circunstancias en las que María fue concebida. Circunstancias de sufrimiento y de constantes rogativas finalmente coronadas por el logro, en las que Juana de la Cruz supo enmarcar en la verdadera cuestión de fondo: el problema social e individual de la esterilidad femenina. Algunos de los detalles que Juana de la Cruz ofrece sobre esta cuestión pueden ser rastreados en el Protoevangelio de Santiago, un difundido relato apócrifo sobre la vida de la Virgen. Nuestra autora conoce también la tradición bíblica de las mujeres estériles, pensemos en Sara, Rebeca o Esther ${ }^{31}$, esposas de los grandes personajes de la Ley Antigua. Como ellas, Santa Ana fue tenida según la ley ebraica, por mañera e desechada por quanto no había fruto (f. 286). Sufrió por ello numerosas persecuciones. Haciéndose eco de las tradiciones vehiculadas por los evangelios apócrifos, Juana narra cómo Ana y Joaquín, su marido, fueron expulsados del templo a causa de su esterilidad y cómo fueron despreciados por muchos, porque no tenían fijos ni acreçentavan generaçión en el pueblo de Isrrael (ff. 286v-287r). Dejaba así constancia del valor político de un hecho biológico, la procreación. Ana, la mujer, sufrió en sus propias carnes el desprecio y la persecución de sus convecinos, los judíos. Cuando iba por las calles oía cómo quienes se topaban con ella le decían: ésta es la mañera, apedreémosla e aún mereçe que le descalçemos su çapato e le escupamos e le demos con él después en la cara (f. 286v).

Reparemos en la modalidad de afrenta que recoge Juana de la Cruz en este sermón, pues guarda extraordinario parecido con el rito utilizado en las sociedades judías contra los varones que se negaban a cumplir con el precepto

\footnotetext{
30 Encontramos este sermón en Conhorte, Biblioteca de El Escorial, Ms. J-II-18, ff. 286v293r. En adelante todas las citas remiten a este manuscrito.

${ }_{31}$ Mañera es el nombre que se daba a las mujeres estériles, sobre este tema en la tradición hebraica que Juana de la Cruz parece conocer y tiene presente véase: M. Ventura, Sterilità e fecondità.
} 
del levirato ${ }^{32}$. El levirato es una norma bíblica (Dt. 25, 5-10) concisa, somera pero concluyente, afirma Olga Ruiz, por la cual el hermano del marido difunto sin hijos está obligado a contraer matrimonio con su viuda. El propósito es engendrar hijos, el mayor de los cuales será considerado descendiente del fallecido, de manera que su nombre perdure tras su muerte. El texto bíblico recoge también el procedimiento a seguir en el caso de que el hermano del fallecido no quiera contraer matrimonio con su viuda. Se detalla así el ritual:

Pero si al hombre no le agrada tomar a su cuñada, ésta subirá a la puerta, adonde los ancianos, y dirá: "Mi cuñado se niega a perpetuar el nombre de su hermano en Israel; no quiere cumplirme la ley del leviraro". Entonces los ancianos de aquella ciudad le citarán para interpelarle. Si se presenta y dice: "No me place tomarla [por esposa]", su cuñada se acercará a él en presencia de los ancianos, le quitará la sandalia de su pie y le escupirá a la cara, y, tomando la palabra, dirá: “iAsí se hace con el hombre que no quiere edificar la casa de su hermano!". Y le apodará en Israel: Familia del descalzado ${ }^{33}$.

Esta es la ceremonia de la halitzah, que se realiza ante los ancianos y se considera, ya en el texto bíblico, como un castigo social para el levir. La mujer es la encargada de avergonzarlo ante la comunidad mediante los tres pasos indicados: quitándole la sandalia, escupiéndole a la cara y dándole el nombre público del "descalzado". Podemos decir que en el imaginario de persecución plasmado por Juana de la Cruz, Santa Ana sufre un modo de afrenta similar. Si partimos del hecho de que el matrimonio de leviraro tiene como principal propósito dar descendencia al varón fallecido, cubriendo así la necesidad de ser eterno mediante la perpetuación de su nombre y mediante una descendencia que lo recuerde, la infracción social de Santa Ana como mujer mañera se hace semejante a la del hombre que rechaza el levirato, en tanto que no aporta hijos al pueblo de Israel. Se podría explicar así el porqué de este paralelo ritual destacado por nuestra monja visionaria ${ }^{34}$.

Juana tiene ocasión completar su descripción de la historia añadiendo matices relacionados con la vivencia subjetiva de la mujer, sus sentimientos de vergüenza ${ }^{35}$.

${ }^{32}$ Seguimos, fundamentalmente a O. Ruiz, El Levirato, p. 213. Véase también E. Cantera, La mujer judía, p. 137-140.

${ }^{33}$ Las referencias completas en Dt. 25, 5-10.

${ }^{34}$ O. Ruiz Morell, El Levirato, p. 217-220.

35 "E como ella era mujer de tan grande oraçión e tan perseguida e corrida de todos, porque era así mañera, muchas vezes deseava ir al tenplo de Dios a orar e no osaba de vergüenza" (f. 287r). Sobre la vergüenza como un importante valor en las sociedades medievales véanse: A. Careño, La vergüenza; J.M. Cacho, La vergüenza; idem, Vergüenza, sabiduría. 
En este contexto de persecución social ligada a la esterilidad se conforma un perfil de mujer espiritual fuerte y decidida que no excluye la paciencia ni la humildad. Como la vergüenza le impedía ir al templo, Ana se encerraba en un vergel que tenía en su casa donde oraba y rogaba al Señor que le concediese,

fruto de su vientre (...) "porque ella conoçiese que no hera aborreçida ni desamparada de él" (...) E porque siguiera ella tuviese alguna consolaçión e no viviese tan triste e angustiada en este mundo" (f. 287r).

En estas súplicas afloran dos nuevos registros emocionales en la vida de la mujer mañera, la tristeza y la angustia, sentimientos que se suman a la ya pesada carga de la vergüenza.

Al cabo de veinticinco años de oración, penitencia, retiro y de prolongadas lágrimas, las súplicas de Santa Ana hallaron respuesta. Así fue cómo tuvo lugar una concepción milagrosa en la que unos avejentados Ana y Joaquín concibieron sin mediación de pecado de concupiscencia a una María que $a b$ initio estaba predestinada en la mente del Padre ${ }^{36}$.

Juana prolonga el argumento de las penas y penalidades de Ana, fortaleciéndolo con un criterio temporal, aquellos veinticinco años de constante sin vivir. Cuando finalmente recibe el anuncio angélico de su inminente concepción, remedo de la escena de la Anunciación en la que el ángel Gabriel anuncia su maternidad a María, Juana de la Cruz revoca el estigma de la esterilidad femenina poniendo en la voz del Señor estas palabras,

No pienses, Ana, que aunque Dios no te diera fruto por eso fueras maldita ni aborreçida de él, que si el Señor dexa de dar fruto [a] algunas personas, no lo faze porque las tiene aborreçidas, mas por su mayor bien y salvaçión. E quien, al contrario de esto pensare, peca en ello y enoja mucho a Dios (f. 288r).

36 J. Fradejas, Los evangelios apócrifos, p. 4, censa las siguientes vidas de santa Ana: del siglo XIII, Alfonso X, Cantiga 411; y "Vida de San Joaquín y Santa Ana", incluida en Grande e General Historia, parte III; Santa Ana es incorporada a la relación de mujeres que compila Álvaro de Luna en su Libro de las virtuosas e claras mugeres, (1446); en 1485 Joan Roís de Corella escribió Historia de Sancta Anna mare de Nostra Senyora (Valencia); se suma J. de Robles, La vida y excelencias e miraglos de Santa Anna y de la gloriosa, (1511); de 1520 data La Visitación de Nuestra Señora Santa Ysabel. La vida de Sancta Ana...nuevamente trovada (Valencia) pliego suelto; y de 1523 la Vida y generación, excelencias y miraglos de la gloriosa Santa Ana (Salamanca). En todas estas obras se incluyen narrativas de la concepción de María en el vientre de Ana. Cabe añadir a este listado el relato que ofrece (entre 1454 y 1468) el dominico Juan López de Salamanca a la condesa doña Leonor de Pimentel en el Libro de las Historias de Nuestra Señora, pp. 33-110. 
Enmarcada en una clara contraposición de la Vieja y la Nueva ley, estas palabras del Señor tienen el poder de sancionar un caso más de revocación de una norma o ley judía poco favorable para las mujeres, hecho que confiere al catolicismo un plus de valor, en tanto que marco igualador de los sexos ${ }^{37}$.

Esta dolorosa experiencia de la esterilidad encuentra en el sermón de Santa Ana un perfecto contrapunto con la exaltación de la fertilidad del cuerpo materno, realidad que se concreta en sencillas pero a la vez potentes imágenes plasmadas en un vitalista lenguaje de alegorías vegetales. Así por ejemplo, cuando recibe del ángel el anuncio de su maternidad, éste le comunica Sábete, Ana, que lo que de ti naçiere será una flor muy preçiosa e olorosa (f. 288r). Este referente simbólico nos lleva a fijar la atención en el modo de nombrar la maternidad, esa gracia primero vedada y luego concedida, tantas veces verbaliza con la expresión tener "fruto" de su vientre. Pero se dan más indicios, en el jardín de su casa, escenario de aquellos años de prolongadas súplicas, Santa Ana tenía un lugar destinado a la oración, cuyo suelo dejaban regado las lágrimas de sus tribulaciones. Allí, en el mismo sitio donde fincaba los finojos, permitió el señor que al cabo de un tiempo naciese,

una mata muy grande e fermosa e olorosa assí como de calabaça; e de aquella mata naçió una flor muy fresca, de la qual flor se fizo una calabaça muy verde e tallada con el cuello muy tallado y bien fecho (f. 287r).

Es esta la primera de una serie de alegorías vegetales, imágenes de vida y generación, de las que el Señor le revela también su significado, que tienen como fin evidenciar y ensalzar la maternidad de Santa Ana y su protagonismo como raíz y origen de las dos figuras centrales de la Historia de la salvación: María y Jesús. En el sermón de Juana de Cruz, guiado como tantos otros por la motivación de enseñar a los fieles, Ana pide explicación al Señor sobre esta figura y éste responde:

E declaró su divina Majestad diziendo que la mata olorosa de la calabaça debaxo de la qual se metían e anparavan los pollos sinificaba la Virgen María nuestra Señora, la qual había de naçer del vientre de Santana, debajo de la qual sombra se avían de anparar e librar todos los pecadores e pobres de virtudes (f. 287v).

En este pasaje se concentran también imágenes de exaltación de la maternidad de $\mathrm{Ana}^{38}$ en virtud de la excelencia de la hija:

37 Otros ejemplos en Á. Muñoz, La nuova legge.

38 Véase, por ejemplo, esa escena que duplica la anunciación del Ángel Gabriel a María cuando tras veinticinco años de ayunos, grandes penitencias, disciplinas y oraciones, un Ángel 
E dixo el Señor que aquella calabaça hera muy tallada de cuello e muy linda a sinificaçión que nuestra señora la Virgen María era y es y será la más fermosa y linda y perfeta e acabada que jamás fue ni será después de Dios (f. 287v).

Es decir, María encarna la perfección humana por encima de cualquier mujer y de cualquier hombre, un argumento que tiene proyección en los primeros textos de la Querella de las Mujeres hispana ${ }^{39}$.

Otras referencias aparentemente accidentales o marginales siguen reforzando el peso que se confiere a la imagen del árbol y las imágenes vegetales. Es el caso de un comentario que Juana introduce en una de las conversaciones que santa Ana cruza con su nieto, el criador del mundo, cuando le dice,

¡Ay, fijo mío muy amado! ¡Vos lo criastes todo; Pues, por çierto quando vos nacistes çielo e sol e luna y estrellas avía; e tanbién había tierra e yerbas e aun estos árboles que aquí están plantados, antes que vuestra madre naçiese estaban ellos aquí naçidos (f. 289r).

No se agotan con ésta las alegorías vegetales que construye Juana de la Cruz con su palabra revelada. Con ellas se corona el tercer y último bloque de este sermón de estructura argumental tripartita. Pero antes de desembocar en el escenario triunfal del Cielo, donde estas alegorías serán escenificadas y posteriormente glosadas en su significado por el Señor, Juana nos adentra en las íntimas relaciones que la anciana Ana y Jesús mantuvieron en vida. Aquí, los personajes de la historia sagrada muestran unas relaciones humanas ancladas en el corazón de la cotidianidad.

La inserción de lo divino en la vida común se expresa en escenas de relación de la abuela y su nieto. Ana es la figura humana que junto a María medió en ese proceso crucial de la incorporación de lo divino a lo carnal humano. Y es la mujer que detenta el estatus privilegiado de ser la abuela de Cristo, desarrollándose entre ambos una relación de amor y confianza que confiere gran autoridad a la abuela.

comunica a Ana: "Sábete Ana que lo que de ti naçiere será una flor muy preçiosa e colorada. E lo que de tu vientre saldrá será una estrella muy resplandeciente que alunbrará todo el mundo" (f. 288r). Juana pone también en María expresiones de reconocimiento del linaje materno, como en la muerte de Santa Ana, donde imagina una escena de duelo en la que el propio Jesús los consuela ("lloraban sus santas fijas e nietos e todos los parientes que allí estaban ayuntados e los consolaba él a todos muy amorosamente e graciosamente e llegaba a su preçiosa madre y echávase en sus brazos consolándola mucho"). Cuando es consolada por el hijo, María exclama: "viváis vos fijo mío muy amado e muérase mi madre e todo mi linage" (f. 291v), anticipándose al dolor que le ocasionaría su muerte en la cruz.

${ }^{39}$ Sobre este tema véase Á. Muñoz, María y el marco teológico. 
Con un lenguaje marcadamente afectivo, Juana de la Cruz explicita reiteradamente en su sermón las palabras que aluden al vínculo parental que los une. Alterna lo narrativo con formas dialógicas donde aparecen expresiones del tipo: Ay, fijo mío muy amado (f. 289r), E agora agüela, so yo venido acá en este mundo (f. 289r); Mirad agüela allí arriba está mi Padre (f. 289r); ¡Ay fija mía!, si vos supiésedes las cosas que yo veo e siento quando tengo a vuestro dulçe e preçioso fijo e nieto mío en mis brazos! (f. 289v); por lo que yo lloro, señora agüela, no vos lo oso dezir (f. 290r); ruego vos amado nieto que no vea yo ni sea viva quando estas cosas ayan de acaeçer (f. 291v); La explicitación del vínculo parental se hace visible también cuando la Virgen María le dice a su hijo ;Ay fijo mío! no vedes cómo se fina vuestra agüela? Sanadla, pues os quiere tanto (f. 291r). O cuando la abuela interviene de nuevo, yo te adoro e doy graçias, Dios mío e nieto mío muy amado, que sanado me has en entrando (f. 291r).

La trama que sustenta estas expresiones son escenas de íntimo trato en las que la abuela además del gozo por las vivencias compartidas con el nieto vive también la angustia de sus penas, anticipo del proceso pasionario que estaba próximo a cumplirse. Lo apreciamos en este pasaje:

E dixo el Señor que quando él era ya mançebo de veinte y çinco años, acordándose quán presto había de morir y ser cruçificado, que, viniendo a casa de su agüela Santa Ana, se echava de pechos sobre un poyo o vanco e allí llorava muy amargosamente e solloçava e gemía e suspirava, con grande angustia e traspasamiento de su anima (f. 290r).

Otro indicio significativo nos reafirma el énfasis que Juana de la Cruz pone en el rol central que desempeña la abuela. También ella, como María, la madre, tuvo el privilegio de la revelación de misterios y secretos tan altos y maravillosos (f. 289v). Ambas mujeres fueron partícipes de secretos de la vida y pasión de Cristo no contados por los evangelistas,

Enpero, como Santa Ana e nuestra Señora eran parte, nunca quisieron descubrir a nadie lo que veían e savían e sentían, por quanto no hera dado a ellas descubrir tales secretos. Que aún de las cosas e maravillas que él fizo siendo hombre de edad perfeta, las cuales maravillas fazían públicas e manifiestas, de diez partes, la una de lo que pasó (f. 289v).

En este contexto de explicitación de lo que parecía obvio en los modelos de relación familiar conocidos por Juana, los estrechos vínculos que anudan en la intimidad de la casa las abuelas y sus nietos, Juana de la Cruz incorpora el relato de la muerte de una Santa Ana, a la que por referencias 
indirectas da el rango de matriarca de una familia extensa ${ }^{40}$. Es a partir del relato de la muerte de la abuela de Cristo cuando se abre el tercer y definitivo escenario del sermón.

Las formas de representación de las estructuras de parentesco que tienen en Ana su gozne central alcanzan su cénit en una alegoría ambientada en el Cielo, lugar al que Ana llega después de su muerte. Como es sabido por quienes están familiarizados con este texto, el Cielo y sus representaciones son en el Conhorte un lugar central en el que se sancionan imágenes y significados nuevos. Cuando Ana llegó a estas regiones celestes, el mismo Dios quiso dar la bienvenida a su santa "abuela" celebrando una fiesta. En una de sus significativas escenas de llamamiento a la fiesta celestial, la más significativa seguramente, la voz del Señor lanza la siguiente convocatoria: salga la rrayz de Ysay e venga delante del trono rreal (f. 291v). Todos los referentes genealógicos de Cristo, convencionalmente asentados por las escrituras y por las interpretaciones histórico-genealógicas en uso, parecen condensarse en este fragmento. Pero ante este primer llamamiento se pide una aclaración:

E oyendo las doze tribus de Isrrael la voz de las trompetas fincaban los finojos con grande humilldad e obediençia diciendo: "Señor Dios señala e declara a quien llamas que oímos la tu voz e no sabemos a quien dizes, porque estamos aquí muchos de ese linage" (f. 291v).

Y llega la rectificación que va a transformar radicalmente la performatividad ritual de la ceremonia que se va a escenificar. Lo apreciamos en el segundo llamamiento que aclara quienes son los participantes rituales convocados, las mujeres:

$\mathrm{Y}$ entonçes tornaron a llamar las trompetas diziendo: "venga la rrayz de Gesé y salgan todas las mugeres que fueron antes que mi madre y echen sus bolsas delante de mi trono". E luego salieron todas las bienventuradas mugeres de las doze tribus trayendo en sus çintas unas bolsas muy lindas e rresplandeçentes más que de oro. $Y$ echaba cada una la suya delante el trono rreal con grande humilldad e rreverencia (f. 291v).

Esta singular y significativa revocación de los modelos genealógicos al uso, modelos que como queda dicho solían silenciar la representación de

\footnotetext{
${ }^{40}$ Por ejemplo, cuando piensa que los lloros de Jesús obedecen al conocimiento de la muerte próxima de su madre, María exclama: "Señor...liévame esotras dos fijas, e a mí con ellas, e no me lleves a la mi deseada e a la mi prometida e anunçiada por los ángeles" (f. 290r). O cuando comenta: "E dixo el Señor que, quando hubo espirado la gloriosa Santa Ana, lloraban sus santas fijas e nietos e todos los parientes que allí estavan ayuntados" (f. 291v).
} 
los hitos maternos, prosigue con el homenaje celestial que exalta y glorifica a la abuela de Cristo:

E dixo el Señor, que entonces fabló él diziendo: "Salga la que yo amo y eche su bolsa, que bien me entenderá ella". E luego salió la gloriosa Santana, e púsose en medio de las otras dueñas e estando ella assí en pie, saltó la bolsa que ella tenía en la çinta e cayó en tierra sin sentirlo ella, e la bolsa hera muy linda e reesplandeçiente e olorosa e toda llena de botones de oro e de espejos muy claros en los quales se aparecía la santísima Trinidad (f. 292r).

Recoge esta alegoría una triple exaltación femenina que afecta al colectivo de las "mujeres" de cuyos vientres salieron criaturas santas que sirvieron a Dios: a Santa Ana, cuya bolsa era más hermosa, clara y olorosa que todas las otras; y a María, fruto de su añoso vientre, la más santa e más pura e limpia que todas las criaturas. Para conjurar interpretaciones mal fundadas, cómo no, también en esta ocasión el Señor ofrece a Juana el significado de la alegoría $^{41}$.

En esta poética alegoría de la generación, Ana, estando en contemplación, observó cómo su bolsa, símbolo evidente del útero femenino, se metía debajo de tierra y de ella nacía una verga muy verde, representación de la Virgen María, de la que salían tres flores, una colorada, otra morada y la tercera blanca, en representación de las tres personas de la Trinidad. Cuando llegó el momento de ofrecer la explicación alegórica, Juana, hablando siempre por boca del Señor, alega:

E aquella tan fermosa verga sinificava a nuestra señora por cuanto la figura la Santa Escritura a oliva muy verde e a açuçena muy fresca e a otros muchos olores aromáticos. E la rrayz de la verga sinificava a la gloriosa Santana, la qual es llamada en el çielo rrayz de Gesé y rrayz de Ysaí, por quanto ella fue del linage de Ysaí. E declaró el Señor diziendo que de la rrayz que era Santana naçió la verga muy fresca y olorosa que era nuestra señora la Virgen María de la qual naçió él. E las tres flores que naçieron de la verga sinificavan la santísima Trinidad. E la flor morada sinificava el padre, al qual es debido todo amor. Y en el cual está todo el poder. E la colorada sinificava el fijo, el qual fue todo muy teñido e colorado en la su sangre preçiosa; e la blanca sinificava el Espíritu Santo, por razón de la su puridad e limpieza e suavi-

\footnotetext{
41 "E declaró su Magestad diziendo que las bolsas que él mandó echar aquellas bienaventuradas mugeres sinificaba los frutos que dieron de sus vientres. Porque así como las bolsas están colgadas de las çintas, así de las çinturas de sus vientres salieron criaturas santas que sirvieron a Dios. E la bolsa de Santa Ana era más hermosa y clara y olorosa que todas las otras, a sinificación del fruto que salió de su vientre, el cual era nuestra señora la Virgen María e más santa e más pura e limpia que todas las criaturas" (f. 292r). La cursiva es mía.
} 
dad. E a desora cresçió aquella verga tanto que en breve espacio llegó fasta la Santísima Trinidad. E estando la gloriosa Santana y todos aquellos pueblos mirando la verga con las tres flores como subían en alto, a desora vieron todos las tres flores ser convertidas en la morada. A sinificación que en el seno e divinidad del Padre se encierra el Hijo y el Espíritu Santo e del rresçiben todo el poder e fuerças. E a sinificaçión que aunque son tres personas distintas conviene a saber, el Padre y el Hijo y el Espíritu Santo, son tres magestades mas una magestad e un poder e una esençia (f. $292 \mathrm{v})^{42}$.

Apreciamos en este texto el trascendental cambio de sentido que lleva a cabo Juana de la Cruz. Arropada con toda la fuerza autoritativa que le confiere la palabra revelada, palabra que la lógica del Conhorte se transmuta en escritura sagrada ${ }^{43}$, desplaza el protagonismo masculino en una estructura fundamental de la memoria genealógica de su tiempo. Con su sermón reforma y transforma los enunciados narrativos e iconográficos del Árbol de Jesé. De modo que en el Cielo, lugar donde reina y se impone la verdad de las cosas, Santa Ana, a la que se llama raíz de Jesé, es reconocida como raíz de la rama (verga) en cuyo cuerpo arraigan las raíces del árbol genealógico de Cristo. María, la rama o verga, Cristo y por extensión la santa Trinidad, se enraízan en el cuerpo de la matriarca, dejando al lado el referente de Jesé. Por otro lado, la flor trinitaria que corona esta alegoría arbórea indica que el misterio de las tres personas de la divinidad pasa por el lugar mediador del cuerpo de la abuela. Al poner el énfasis en una fracción genealógica más vinculada, quizás, a la realidad simbólica del árbol de la vida, un elemento de proyección transcultural que arraigó con fuerza las religiones cristiana, musulmana y judía ${ }^{44}$, Juana se afianza en la evidencia de los cuerpos maternos como fundamento de significado teológico, pero también social.

Es sabido que la imagen del árbol de Jesé fue ampliamente utilizada en los tratados favorables a la integración de los judeoconversos ${ }^{45}$. Ya había sido utilizada por Juan de Torquemada en su Tratado contra los Damianitas, como imagen que reforzaba el argumento de la "paz y concordia" que debía reinar entre el pueblo de los gentiles y el de Cristo ${ }^{46}$. También fue una ima-

${ }^{42}$ La cursiva es mía.

${ }^{43}$ R. Surtz, The Guitar.

${ }^{44}$ Véase C. Robinson, Trees of Love y J. Guerrero, Sobre el origen.

${ }^{45}$ Este tema es destacado por F. Pereda en La puerta de los Leones, trabajo en el que ofrece una documentada discusión sobre las fuentes del motivo del árbol del Jesé y su eco en la iconografía.

${ }^{46}$ De esta paz y concordia que ha de establecerse entre estos dos pueblos mediante la venida del Hijo de Dios, se dice expresamente en Isaías 11, 1 y 6: "Saldrá una vara de la raíz de Jesé", véase C. del Valle (ed.), Tratado contra los madianitas, p. 321. 
gen relevante para Alonso de Cartagena, autor del ya comentado Defensorium Unitatis Christianae. Y para Fray Alonso de Oropesa, en cuyo tratado Luz para conocimiento de Gentiles, (h. 1462), la metáfora del árbol es recurrente. En el capítulo XXXVIII de su tratado, Oropesa ilustraba la Unidad pacífica, igualdad y concordia de todos los fieles apoyado en un significativo pasaje del Libro de Isaías tradicionalmente interpretado como un canto de paz y unidad de la Iglesia. En uno de sus pasajes se podía leer: Aquí se llama a Cristo raíz de Jesé porque es de su descendencia según la carne ${ }^{47}$. Una expresión que concuerda con el decisivo fragmento, E la rrayz de la verga sinificava a la gloriosa Santana, la qual es llamada en el çielo rraiz de Gesé e rraiz de Ysaí, que documentamos en el sermón de Santa Ana de Juana de Cruz.

El tema de la raíz resuena también en diversos pasajes del Nobiliario Vero de Ferrán Mexía. Uno de ellos cuando comenta: e así el linaje que primero se llamava de Lara llamose Manrrique del qual su "rrais" e fundamento fue e es el dicho linaje del solar de Lara ${ }^{48}$. O en este otro,

E si alguno oviere de ser más noble será el quinto quel primero. Más noble será el quinto quel primero. Por quel quinto ya trae generación de donde toma rayzes la nobleza. Lo qual el primero no tiene como vemos en las plantas. Que un árbol que será de llevar fruto arránquenlo e pónganlo en otro lugar ese año no llevará fruto. E si otro por ventura llieva no será como el terçero. Ni el del terçero como el del quarto ni el del quarto como del quinto. E así fasta que tiene el dicho árbol afirmadas su rrayzes donde fue criado. Ca aquello quiso dezir la sagrada escritura quando fabló de la verga que salió de la rrays de Yese o de la flor que proçedió de la dicha verga. $\mathrm{Ca}$ allí tomose por fundamento la rrays para dar loor a la Reyna de los çielos gloriosa de la qual rrays fablaron para endereçar el loor ${ }^{49}$.

En estas palabras de Ferrán Mexía podemos apreciamos la honda tradición textual sobre la que se levanta el giro de sentido que introduce nuestra autora en su visión del árbol de Jesé.

En 1510 llegó a la imprenta un escrito de Juan de Robles, un canónigo regular de San Isidoro de León, que vio la luz con el título La vida y excelencias e miraglos de Santa Ana. Robles, un coetáneo de Juana de la Cruz, ya se hacía eco en su libro de cómo era costumbre de la ley en el escrevir e contar de los linajes se pusiesen e nombrasen siempre los maridos e no las mujeres $^{50}$. Una idea que testimoniaba varias décadas antes el propio Alonso de

47 A. de Oropesa, Luz para el conocimiento, p. 465.

${ }^{48}$ F. Mexia, Nobiliario vero, LII, cap. XVI.

49 Ibidem.

50 A. Muñoz, La reescritura de los símbolos, p. 151. 
Madrigal ${ }^{51}$ y que nobiliarios como el del Ferrán Mexía, la literatura histórica de la época, y las prácticas sociales refrendaban.

La alegoría vegetal de Juana de la Cruz culmina con un acto de exaltación de la abuela de Dios que condensa y proclama todos estos significados anteriores. Los patriarcas, protagonistas desplazados del primer llamamiento y de los relatos genealógicos sobre los que se construye la historia, se sientan ahora en las mesas del banquete celestial, remedo del banquete eucarístico, dejándose servir por una Santa Ana que actúa libre de todo tabú de contacto con la divinidad:

E como estaban ayuntados allí, dijo el Señor, muchos pueblos del linage de Abrahan, e de Isac y de Jacob e de Ysay e de David, los quales avían venido al llamamiento de las trompetas, él los mandó asentar a todos a unas muy fermosas mesas. E la gloriosa Santana le tomó a él en braços e le llevaba a todos los que estavan asentados a las mesas para que le adorasen e sirviesen. E quando los bienaventurados le veían venir, tendíanse todos por suelo e adorábanle con soberana rreverencia besándole sus sagrados pies e manos. Y él mesmo fue el manjar en aquel preçioso convite (f. 293r).

A continuación, invirtiendo el orden de las pasadas relaciones familiares vividas en la tierra, Santa Ana es llevada por Cristo entre sus brazos en una escena pletórica de gestos ensalzadores. El Señor tomó a su abuela en brazos, la subió consigo al trono celestial y la hizo coronar por toda la Santísima Trinidad:

E después, dixo su divina magestad, tomó él en sus braços a su santa agüela e la subió consigo a su trono rreal; e la ofreçió al Padre çelestial. E allí la coronó toda la Santísima Trinidad e le dio grandes gozos açidentales e fizo merçedes por amor de ella a todos sus devotos e a todos los que facen de ella fiesta o memoria (f. 293).

Santa Ana, pues, es la protagonista de una coronatio al estilo que ofrecen las vírgenes en cuaternidad, aquellas en las que la Virgen María es

51 Juan de Robles explicita una realidad ya reconocida a mediados del siglo XV por Alonso de Madrigal quien, refiriéndose a la diosa Juno, comenta: "Según de Apolo y de Neptuno deximos, aviamos de dezir de Juno quien y quantos fueron sus fijos. Empero en esto repugnan dos cosas. La primera es que Juno es hembra y los fijos no se cuentan a las mujeres, mas a los varones. Y como ella tenga marido a Júpiter avíanse de nombrar todos los fijos de Júpiter y no contarse por línea de Juno" (Las diez questiones vulgares, cap. XIV, "De los hijos de Juno") véase, Á. Muñoz, Las cuestiones. 
coronada por la Trinidad ${ }^{52}$. Las implicaciones teológicas de la encarnación de la divinidad en un cuerpo femenino nos conducen al misterio de las tres flores que surgían de la rama o tallo del que Ana era la raíz, flores que se fundían en una sola esencia, por mor de la comunicación de la materia y la conectividad de los fluidos, y entreabrían la puerta a la idea de Ana como lugar de enraizamiento de mismísima Trinidad. Pero además, se da entrada a la cuestión del cuerpo femenino que concibe, gesta y da a luz, recolocándolo en espacios de singular revaloración simbólica. Recordemos la afirmación vertida en otro sermón de Juana de la Cruz, el dedicado a la Inmaculada Concepción de María, donde nuestra inspirada terciaria afirmaba, "de la que Dios tomó carne Dios puede ser llamada". Este es el régimen de la carne, despreciado por Alonso de Cartagena, en el que podían verse rehabilitadas todas las mujeres.

\section{LAS GENEALOGÍAS FEMENINAS EN EL MARCO DEL GIRO GENEALÓGICO DEL SIGLO XV: CONSIDERACIONES SOBRE EL ESTATUTO CULTURAL DEL SERMÓN DE SANTA ANA}

Retornemos de nuevo a los planteamientos de índole estructural que recorren la Baja Edad Media hispana en materia de cultura genealógica, para así tratar de contextualizar y dimensionar oportunamente las palabras de Juana de la Cruz. La noción de "giro genealógico" nos resultará de gran utilidad para este propósito.

La obsesión española por la hidalguía, la descendencia gótica y la pureza de sangre ha constituido un extendido estereotipo en nuestra tradición historiográfica. Los orígenes históricos del énfasis en el linaje es uno de los temas más polémicos de los estudios especializados en la identidad hispana y sefardita. En uno de sus más aplaudidos estudios, David Nirenberg ha puesto de manifiesto cómo el énfasis que pusieron en el linaje los españoles y los sefarditas no fue producto de una transmisión "genética" de ideas de una cultura (la judía) a otra (la cristiana), sino consecuencia de un proceso histórico de conflicto en el cual el linaje se convirtió en una nueva significativa vía para pensar la identidad religiosa, tanto entre cristianos como entre judíos. Entre 1391 y 1414, señala este autor, como consecuencia de los procesos de conversión al cristianismo que protagonizaron tantos judíos (entre ellos estuvo la familia del Alonso de Cartagena) se produjo una violenta desestabilización de las categorías tradicionales de identidad religiosa cuyas consecuencias se mantendrían a lo largo de los siglos XV y XVI. Ante esta desestabilización,

\footnotetext{
${ }^{52}$ Sobre el sermón de la Trinidad véase R. Surtz, The Privileging.
} 
cristianos, judíos y conversos crearon nuevas formas de identidad comunitaria. Mediante un dinámico y dialógico proceso de relectura de sus propias tradiciones y de las tradiciones de sus rivales llevado a cabo a lo largo del cuatrocientos, este proceso elevó la genealogía a una forma primaria de memoria comunitaria. En cada una de estas comunidades esta forma de memoria genealógica colectiva dio lugar a nuevas expresiones de conocimiento y de escritura históricas ${ }^{53}$. Es también en este siglo cuando la genealogía produce narrativas o sistemas de conocimiento en torno a los cuales una gran escala de entidades políticas, sociales, religiosas o étnicas logró coherencia ${ }^{54}$. En un contexto de crisis clasificatoria en el que importaba neutralizar las franjas de intercambio y mistificación, estos instrumentos de memoria genealógica fueron claramente desplegados en el interés de afirmar la superioridad de los linajes individuales. Tal fue la relevancia que alcanzó la noción de linaje en numerosos ámbitos de las sociedades hispanas de esta centuria, que David Nirenberg propone hablar de un verdadero giro genealógico. Este giro genealógico que se manifestó en frentes muy diversos, fue en sí mismo un intento de encubrir o disimular rupturas mediante el establecimiento de nuevas continuidades, nuevos lazos entre la familia, la raza, la fe y la nación ${ }^{55}$. En este mismo contexto cultural se activó con fuerza el debate sobre la caballería y la nobleza, en cuyo trasfondo vuelve a estar el tema de las genealogías y el linaje.

En este entramado histórico de gran calado es pertinente introducir los originales planteamientos de Juana de la Cruz como exponente de la intervención femenina en las controversias de su época. Como se ha podido observar, nuestra autora rectifica radicalmente la descripción e interpretación de un modelo genealógico extensamente arraigado en la cultura medieval. Quién esté en la base o raíz, quién en las ramas y quién en la cima del árbol, está sujeto a variantes que se elevan a claves de hermenéutica visual ligadas a un frente de debate en el que Teología y cristología cruzan elementos con la Querella de las Mujeres. Juana contestaba imágenes muy arraigadas, ampliamente disponibles en la tradición cultural y en su propio contexto histórico. Pudo escuchar o leer el tratado de San Ildefonso sobre la virginidad de María, donde se decía a propósito de la madre de Cristo: Es según Isaías, vara de la Raíz de Jesé, esto es nacida de su linaje, virgen que produjo esa flor, Cristo, por espiritual influencia y sin allegamiento corruptible de varón. En la Biblia iluminada del siglo XIII de la Catedral de Toledo se recoge la afirmación, Virga Jesse significat Mariam. Juana pudo ver el tímpano de la Puerta de

${ }^{53}$ D. Nirenberg, Mass Conversion, pp. 6-7.

${ }^{54}$ Ibidem, p. 9.

55 Ibidem, p. 40. 
los Leones de la Catedral de Toledo, escenario de gran significado litúrgico, donde también se utilizaba el recurso del árbol de Jesé para afirmar valores de regeneración y resurrección ${ }^{56}$.

El enfoque subversivo con el que Juana de la Cruz valora la cuestión del linaje de Cristo, realzando el protagonismo de santa Ana, encuentra afinidad con otros testimonios de mujeres coetáneas. La dimensión política de la imagen de Santa Ana y el valor que adquirió como expresión de la conciencia genealógica de las mujeres de la nobleza castellana, es elevada a valencias paradigmáticas con Mencía de Mendoza (1422-1500), esposa del I Condestable de Castilla, una de las más señaladas figuras del mecenazgo artístico castellano de la segunda mitad del siglo XV, cuyas empresas de promoción artística van ligadas a nombres como el arquitecto Simón de Colonia, el escultor Gil de Siloé o el pintor Juan de Flandes. El caso, exhaustivamente documentado y estudiado por el historiador del arte Felipe Pereda ${ }^{57}$, evidencia cómo doña Mencía, no sin conflicto con sus hijos, llevó las riendas de su casa en ausencia de su esposo, durante el tiempo que este estuvo en la guerra de Granada (1482-1492), y más tarde como viuda, con disponibilidad económica de los bienes patrimoniales de la familia, reivindicando el reconocimiento del peso que ella, con la influencia mediadora de su propio linaje, habían tenido en el engrandecimiento del linaje de su marido e hijos. Doña Mencía acometió un extenso programa de patronazgo artístico que le permitió intervenir en su propia casa, conocida como la Casa del Cordón, en una quinta conocida como la Quinta de la Vega y en la catedral de Burgos, donde construyó una capilla funeraria dedicada a la Purificación, hoy conocida como la capilla del Condestable, destinada a albergar sus restos mortales y los de su esposo. Con esta construcción doña Mencía introducía una ruptura con los espacios funerarios de los Velasco fundando uno nuevo en el que se integraba en régimen de igualdad con su propia memoria familiar. En la capilla de la Purificación de la Catedral de Burgos, una joya de la arquitectura del cuatrocientos, diseñó meticulosamente los elementos materiales y la liturgia funeraria que había de seguirse. En ella encontramos un altar dedicado a la Santa Ana triple.

Los detalles de la fundación de Mencía de Mendoza nos dan cuenta de la aguda conciencia de linaje que guiaba sus pasos. Siguiendo la explicación de Felipe Pereda, el programa litúrgico e iconográfico que dejó ordenado preveía una división simétrica de la capilla en dos ámbitos, el masculino y el femenino, dedicados respectivamente al Condestable y a su esposa. En el crucero norte habría un altar con la advocación de San Pedro y en el sur otro

${ }^{56}$ F. Pereda, La Puerta de los Leones, pp. 170 y ss.

${ }^{57}$ F. Pereda, Mencía de Mendoza. 
ofrecido a santa Ana. En el lateral de este último se fijaba un escudo sustentado por dos ángeles, el de los Mendoza-Figueroa, el único visible desde el centro de la capilla. Además, según documenta Felipe Pereda, los primeros estatutos de la capilla fueron suscritos inmediatamente después de la muerte de la Condesa y determinaban un orden jerárquico entre los dos altares, ya que la primera misa del año debía decirse en el altar de la Condesa, y sólo después en el de San Pedro.

En el altar de Santa Ana se instaló una imagen de Gil de Siloé que seguía el modelo iconográfico establecido en los talleres de Malinas donde se funde en una única figura dos tradiciones iconográficas diferentes: la Santa Ana "trinitaria" que como una matriarca alza a su hija y a su nieto y la Santa Ana "maestra" que enseña las primeras letras a su hija en un libro Por los inventarios de bienes de doña Mecía se sabe tenía otras dos imágenes de esta santa, alojada en una de las ermitas de su jardín una de ellas y otra, realizada en oro que guardaba en su cámara.

El retablo de Santa Ana donde se plasma "la misma obsesión heráldica que el resto de la capilla", apunta Felipe Pereda, presenta una particularidad que disiente de la decoración esculpida en los muros. Salvo en el caso del mencionado escudo lateral, en todos los otros casos en los que quedan figuradas las armas de la Condesa se plasman por separado los escudos del linaje paterno (Mendoza) y del materno (las cinco hojas de higuera, de Figueroa). Las armas de los Mendoza se sitúan bajo Santa Isabel; las de los Figueroa, bajo Santa Helena. Entre ambas, sobre la torre matriarcal de la Santa Ana, en su misma calle fue ubicada la figura de Santa Catalina de Alejandría. Las armas que lleva Catalina a sus pies son las de Figueroa. La madre de Mencía de Mendoza se llamaba Catalina de Figueroa.

Elementos comunes parecen señalar fuertes similitudes entre las elecciones figurativas de Mencía de Mendoza, construidas y perpetuadas con el lenguaje de las artes visuales y las imágenes de Juana de la Cruz, construidas con palabras que se inmortalizaron gracias a la iniciativa de escritura de sus compañeras de comunidad. Las dos se aferran a la imagen de Santa Ana. Como Juana de la Cruz, Mencía de Mendoza proclamaba el reconocimiento de la memoria y la autoridad materna. Santa Ana fue un icono en la defensa del principio materno y de rol genealógico femenino que interactuaba y reacciona a la vez con un hecho significativo, la ocultación, o minimización de las madres en este contexto de generalización de las mentalidades genealógicas sobre las que se asienta el estatuto personal de los individuos. En el fondo de esta reivindicación se trasluce un complejo panorama de cambios sociales,

58 Ibidem, pp. 81 y ss.

ANUARIO DE Estudios MedieVAles, 44/1, enero-junio 2014, pp. 433-473 ISSN 0066-5061, doi:10.3989/aem.2014.44.1.14 
jurídicos y políticos, que afectaban negativamente a las mujeres. Lo materno concentra muchos potenciales significados que estos procesos sociales y políticos del cuatrocientos ponían en cuestión. Las madres resultaron ser esa pieza necesaria que se ocultaba en las genealogías, eran sujetos que retrocedían en derechos y reconocimiento, quizá también en expectativas de acción en el marco de ese giro genealógico que se radicaliza en la cultura del siglo XV.

Como vimos páginas atrás, la voz linaje, como criterio de clasificación de individuos ofrece en la lengua castellana del siglo XV diversas asociaciones léxicas. Sin embargo, no se ha destacado suficientemente que voces como estado y linaje se aplicaron también en las fuentes narrativas didácticas del siglo XV al colectivo femenino. Expresiones como linaje femenino o femenil se plasmaron en los primeros tratados de defensa de las mujeres, tratados que mantienen un claro vínculo contextual con otros centrados en la discusión sobre la nobleza. No es casual que dos de los primeros tratadistas que intervienen en el debate de la Querella de las Mujeres escriban también tratados sobre la nobleza. Juan Rodríguez del Padrón autor del Triunfo de las donas, redactó por el mismo tiempo Cadira de Honor ${ }^{59}$. A Diego de Valera, a su vez, debemos el Tratado de Defensa de virtuosas mujeres y el Espejo de verdadera nobleza $a^{60} . ¿$ Era esta una forma de incorporar las mujeres al debate político reconociéndoles entidad como un colectivo que, pese a sus diferencias sociales, estaba dotado de características comunes?.

Cuando Juana escribe, los procesos embrionarios que se manifestaban a mediados del XV ya habían alcanzado un alto grado de estructuración: se ha verificado el amplio desarrollo de la polémica judeoconversa y avanzan las teorizaciones sobre la nobleza y el linaje. Entre tanto, las formas de cultura religiosa canalizadas a través del arte, así como el desarrollo de las narrativas de la Vida de Cristo dejaban al descubierto imágenes materno-filiales de otro cariz, modelos familiares no siempre respaldados por los moldes jurídicos del momento. La Vida de Cristo, enunciada en estos términos trastoca las estructuras fundamentales con las que se organiza o formaliza la noción de linaje agnaticio, patrilineal. Este será el tapiz de fondo que le permita desarrollar a nuestra religiosa una narrativa sutil, revocadora, polémica.

La propia Concepción del Hijo de Dios, sin concurso de varón, alentaba en el imaginario religioso de estas mujeres una niveladora percepción del papel insustituible de la madre. Lo apreciamos en este fragmento del Sermón de la Inmaculada Concepción, también de Juana de la Cruz, en el que plasman todos los campos de transferencia que convergen en María: limpieza, nobleza y autonomía

59 J. Rodríguez de la Cámara, Obras, Triunfo, pp. 83- 127 y Cadira de Honor en pp. 131-173.

${ }^{60}$ D. de Valera, Prosistas Castellanos, pp. 55-116. Se destacan los estudios realizados en el campo de la nobleza por J. Rodríguez Velasco, El debate; idem, Ciudadanía. 
de méritos, ya que, precisamente por los méritos en la caracterizaban, Dios se enamoró de ella y obró de manera que la mujer sola parió a Dios y hombre verdadero. Así lo expresan las palabras de la religiosa de Cubas de la Sagra:

E declaró el señor diziendo: Que cómo había de tener mácula de pecado la que fue criada e nasçida para remediar el pecado? E que, por esa pura y sin manzilla Virgen madre suya, dixo él mismo a Abraan: "En tu simiente serán bendecidas todas las gentes". E a David: "De tu generaçión se levantará el que poseerá la silla altísima". E que por eso dixo el ángel Gabriel a Nuestra Señora, cuando la saludó: "este será grande e fijo del muy alto llamado". E darle a el señor Dios la silla de David, su padre. Porque nuestra Señora hera tan limpia que Dios se avía enamorado tanto de ella que había de tomar su carne e ayuntarse con ella e fazerse honbre sin simiente de honbre, mas por obra maravillosa del Espiritu Santo, el qual lo obró de esta manera: que tuviese nuestro señor Jesucristo, Madre en la tierra e Padre en el çielo, conviene a saber, que le pariese e fuese encarnado en la siempre Virgen nuestra Señora. E que le engendrase el Padre celestial, el qual abita en las mayores alturas de todos los çielos. E por esto la crió tan linpia e sin mácula de pecado, lo qual fizo la Santísima Trinidad al contrario en la creaçión de Adán, que, quando le crió, no crió muger con él sino a él sólo. E dentro del mesmo primer honbre quedó encerrada la mujer. E después la parió Adán, porque del mesmo sacó la mujer el Señor. Lo cual fue al contrario en la Santa Encarnación de Nuestro Señor Jesucristo, que la mujer sola parió a Dios e honbre verdadero. E que, así como Eva fue nasçida de varón sin mujer, así por semejante nuestro redentor Jesucristo naçió de mujer sin varón (Sermón no 70. ff. 429r-429v).

No es baladí recordar que en esta historia narrada por Juana de la Cruz, Ana y Joaquín eran ricos y de gran linaje (f. 286v). Ana, por tanto, se erige en matriarca de un linaje nobiliario ${ }^{61}$. La nobleza de la Virgen, ligada a sus excelencias es afirmada en otro pasaje significativo del Conhorte que localizamos en el sermón de la Huida a Egipto. Según relata la voz del Señor por boca de Juana, su elegida, ya instalados en este país de exilio, María y José con el niño alquilaron una pobre casa. Allí padecieron grandes necesidades, hambres y tribulaciones, porque si José iba a alguna tienda a mercar pan o algunas cosas para comer, no se las querían vender, mas antes les daban bofetadas en el rostro y le mesaban y deshonraban a él y al Salvador. Los egipcios exclamaban:

¿A qué vienen acá estos judíos traidores a nuestra tierra, para hurtar nuestras haziendas, que ansí hazían los otros judíos quando los

${ }^{61}$ Sobre las tradiciones populares que circulaban sobre los padres de la Virgen véase J. Fradejas, Los evangelios, pp. 3-32. 
teníamos acá captivos e presos? E viendo a Nuestra Señora tan humillde y ençerrada e cómo sabía hazer de sus manos cosas tan lindas e pulidas, e cómo era tan hermosa y amorosa y bien criada, maravillábanse mucho en sus corasçones, diziendo: Çierto esta bendita mujer no debe de ser de los judíos nazarenos ni de los isrraelitas, que de linage de algunos grandes príncipes o caballeros de la gentilidad deve ser, según las virtudes e bondades que ella tiene (Sermón $n^{\circ}$ 6, ff. 64v-65r).

Significativo desmarque de la Virgen del linaje de los judíos y su asociación al linaje de la gentilidad, pues guarda relación con otro de los referentes polémicos que cursan su trayectoria en suelo castellano durante los tiempos de la polémica religiosa judeoconversa ${ }^{62}$.

La nobleza y la excelencia de María, como variables asociadas, activan nuevos significados en este contexto polémico que discurre entre la segunda mitad del XV y las primeras décadas del siglo XVI, en el que la Querella de las Mujeres, el debate de la caballería y la polémica judeoconversa cruzan trayectorias.

En resumen y concluyendo, en otros lugares he abordado la cuestión de las conexiones de los debates teológicos marianos con la Querella de las Mujeres. Hemos recuperado aquí el argumento a través de un registro textual de extraordinario valor. El sermón de Santa Ana es un testimonio de excepción, ineludible en la cartografía de las controversias marianas, porque nos introduce una voz femenina, quizás los ecos polifónicos de muchas voces femeninas, en estos tiempos aurorales del catolicismo moderno, cuando muchas de las tendencias que se anunciaban a mediados del XV comienzan a sedimentarse. Este tema podría ser rastreado a lo largo de toda la obra de la visionaria toledana, ya que contiene diversos sermones marianos, pero dos de ellos en particular, el dedicado a Santa Ana y el dedicado a la Inmaculada Concepción, son de especial importancia por su contenido y por las peculiares formas controversiales que incorporan. Sus planteamientos no sólo buscan formular doctrinas, en lo tocante a valores y agencias femeninas contrarias a los de dominio común en la sociedad de su tiempo, sino que van mucho más allá. En este caso, al ser el propio Dios la fuente de los dictados revelados a Juana, y al adoptar su palabra revelada el rango de escritura sagrada, podríamos decir que los dictados de Juana de la Cruz tratan de zanjar doctrinalmente la controversia en aquellos vectores que tocan el núcleo de la ontología de los géneros que postula ${ }^{63}$.

${ }^{62}$ Sobre el tema Á. Muñoz, La nuova legge.

63 Sobre el carácter sagrado que asume la palabra revelada de Juana de la Cruz véase R. Surtz, The Guitar, en particular cap. V, "Scripture and Scriptures", pp. 109-142. 
La valoración de la cuestión de los méritos de María condicionados en su explicación por la necesidad del hijo, o ligados al privilegio divino y no a su naturaleza femenina, son referentes de elaboración de la figura mariana que se activan en el siglo XV -pensemos en Alonso de Madrigal- ${ }^{64}$, que se ven radicalmente invalidados en nuestra autora. Los sermones de Juana de la Cruz se caracterizan por transitar núcleos de significación bien distintos. Su especificidad se pone de manifiesto en tres ámbitos fundamentales: 1. En el potente desarrollo de las imágenes de generación (concebir el infinito) que vuelca sobre Santa Ana. 2. En una impugnación de los modelos de memoria genealógica dominantes en las narrativas históricas de la Historia Sagrada, basados por lo común en el linaje agnaticio, que la lleva a reafirmar el significado genealógico de las mujeres, en tanto que madres de los hijos e hijas que componen los linajes. 3. En su valoración de María en relación con la figura del Hijo: los méritos del hijo correlacionan con los méritos de la madre, algo bien distinto a que los méritos de la madre vayan condicionados a los del hijo. Esta manera de ver las cosas queda condensada en la extraordinaria expresión de la que Dios tomó carne, Dios puede ser llamado, que Juana de la Cruz vierte en el sermón de la Inmaculada Concepción ${ }^{65}$.

Elemento compartido, tanto en el frente polémico judeoconverso, como en el intenso debate que se estaba librando sobre la caballería y los procesos de definición interna de la nobleza, la voz linaje resulta ser un conector que emparenta procesos sociales. Pero no solamente procesos identitarios, pues en la voz linaje reposa también la cuestión de la sangre y de la herencia genética, dos realidades que se relacionan directamente con el nacimiento. En el cruce de estas conexiones surge un agente no nombrado, las madres, parte esencial de ese linaje femenil que fue objeto de discusión en la Querella de las Mujeres, el tercer gran debate que se inaugura en el suelo peninsular en la década de los cuarenta del siglo XV.

Valorado desde esta óptica, el sermón de Santa Ana se convierte en una pieza de gran valor. Su estudio nos permite abordar una lectura de Juana de la Cruz y de su obra como expresión de la intervención de algunos conventos femeninos hispanos en un campo cruzado de controversias: la que guarda relación con la Querella de las Mujeres o el debate de los sexos de su momento, debate contextualmente ligado a los otros frentes polémicos de su tiempo, el debate sobre la nobleza y la polémica judeocristiana. Desde este campo de percepción se logra disipar el fantasma de lo anecdótico, de lo curioso o extravagante que planea insistentemente en la valoración de este texto de autoría

${ }^{64}$ Véase Á. Muñoz, María y el marco teológico.

${ }_{65}$ Á. Muñoz, El monacato. 
femenina surgido en un ámbito conventual castellano. Al profundizar en la trama contextual en la surgen las palabras de nuestras autoras y poner de manifiesto sus conexiones con las problemáticas de su sociedad, en las cuales las mujeres parece que intervinieron activamente, no sólo queda reforzado el valor de sus propios discursos y la agencia política y cultural que desempeñaron estas mujeres provenientes del mundo conventual femenino, también se ponen las bases para comprender las implicaciones estructurales de lo que se ha visto como fenómenos periféricos de la historia de las sociedades medievales.

\section{BIBLIOGRAFÍA CITADA}

Archer, Robert, La cuestión odiosa. La mujer en la literatura hispánica tardomedieval, Valencia, Institució Alfons el Magnànim, 2011.

Ashley, K; Sheingorn, P. (eds.), Interpreting Cultural Symbols. Saint Anne in Late Medieval Society, Athens - London, The University of Georgia Press, 1980.

Beltrán de Herencia, Vicente, Miscelánea Beltrán de Heredia: colección de artículos sobre historia de la teología española, vol. III, Salamanca, San Esteban, 1973.

Benito Ruano, Eloy, Toledo en el siglo XV. Vida política, Madrid, CSIC, 1961.

Benito Ruano, Eloy, Los orígenes del problema converso, Madrid, Real Academia de la Historia, 2001.

Bilinkoff, Jodi, Charisma and Controversy, “Archivo Dominicano” 10 (1989), pp. 55-66.

Boon, Jessica A., Mother Juana de la Cruz: Marian Visions and Female Preaching, en Kallendorf, Hilaire (ed.), A New Companion to Hispanic Mysticism, Leiden - Boston, Brill, 2010, pp. 127-148.

Boon, Jessica A., Christ at Heavenly Play: Christology Through Mary's Eyes in the Sermons of Juana de la Cruz (1481-1534), "Archiv für Reformationgeschichte" 102 (2011), pp. 243-266.

Boon, Jessica A., The Glory of the Virgin. The Mariology of the Incarnation in Two Early Modern Castilian Mystical Sermons, "La Corónica: A Journal of Medieval Hispanic Languages, Literatures \& Cultures" 41/1 (2013), pp. 35-60.

Cacho Blecua, Juan Manuel, La vergüenza en el discurso del poder laico desde Alfonso X a don Juan Manuel, en Lucía Mejías, José Manuel (ed.), Actas del VI Congreso de la Asociación Hispánica de Literatura Medieval (Alcalá de Henares, 12-16 de septiembre 1995), vol. I, Alcalá de Henares, Universidad de Alcalá, 1997, pp. 393-411. 
Cacho Blecua, Juan Manuel, Vergüenza, sabiduría y pecado en la literatura medieval castellana (del Bonium a don Juan Manuel), "Principe de Viana" Anejo 18 (2000), pp. 75-102.

Cantera Montenegro, Enrique, La mujer judía en la vida familiar y comunitaria en la Sefarad Medieval, en Moreno Koch, Yolanda; Izquierdo Benito, Ricardo (eds.), Hijas de Israel. Mujeres de Sefarad, Cuenca, Ediciones de la Universidad de Castilla La Mancha, 2010, pp. 123-178.

Careño, Antonio, La vergüenza como constate social y narrativa en don Juan Manuel. El "Ejemplo L" de El Conde Lucanol, "Thesaurus" 32/1(1977), pp. 54-74.

Cátedra, Pedro M., Poesía de Pasión en la Edad Media en el "Cancionero" de Pero Gómez de Ferrol, Salamanca, Publicaciones del SEMIYR, 2001.

Coomarasway, Ananda, The Tree of Jesse and Indian Parallels or Sources, "The Art Bulletin" 10 (1929), pp. 116-120.

Cruz Cruz, Juan, ¿Finalidad femenina de la creación? Antropología bajomedieval de la mujer?, "Anuario Filosófico" 26 (1993), pp. 513-540.

Covarrubias, Sebastián de, Tesoro de la lengua castellana o española, edición de Felipe C.R, Maldonado; revisada por Manuel Camareno, Madrid, Castalia, 1994.

Domínguez Rodríguez, Ana, Iconografía evangélica en las Cantigas de Santa María, "Reales Sitios" 80 (1984), pp. 37-44.

Domínguez Rodríguez, Ana, Del árbol de Jessé de la Catedral de Pamplona y su carácter trinitario, en Aranza J. et al. (eds.), V Simposio Bíblico español. La Biblia en el arte y en la literatura, vol. II, Pamplona, Fundación Bíblica Española, 1999, pp. 187-206.

Domínguez Rodríguez, Ana, La Virgen, rama y raíz. De nuevo el árbol de Jesé en las Cantigas de Santa María, en Montoya Martínez, Jesús; Domínguez Rodríguez, Ana (eds.), El Scriptorium alfonsí: de los libros de Astrología a las "Cantigas de Santa María”, Madrid, Editorial Complutense, 1999, pp. 173-214.

Fradejas Lebrero, José, Los evangelios apócrifos en la literatura española, Madrid, Biblioteca de Autores Cristianos, 2005.

García de Andrés, Inocente (ed.), El Conhorte: sermones de una mujer. La santa Juana (1481-1534), Madrid, Fundación Universitaria Española - Universidad Pontificia de Salamanca, 1999.

Genicot, Léopold, Les généalogies. Typologie des sources du Moyen Age occidental, Turnhout, Brepols, 1975.

Giordano, María Laura, Apologetas de la Fe. Élites conversas entre Inquisición y Patronazgo en España, (Siglos XV y XVI), Madrid, Fundación Universitaria Española, 2004. 
Gonzálvez, Ramón, Fundamentos doctrinales de la sentencia-estatuto de Toledo contra los conversos (1449), en Inquisición y Conversos. III Curso de cultura hispano-judía y sefardí, Toledo, Universidad de Castilla La Mancha, 1994, pp. 279-296.

Gonzálvez, Ramón, El Bachiller Palma y su obra de polémica proconversa, en "Qu'un sang impur...". Les conversos et le pouvoir en Espagne à la fin du Moyen Âge (Actes du 2ème colloque d'Aix-en-Provence, 1820 novembre 1994), Aix-en-Provence, Publications de l’Université de Provence, 1997, pp. 47-59.

Graña Cid, María del Mar, El cuerpo femenino y la dignidad sacerdotal de las mujeres. Claves de autoconciencia feminista en la experiencia mística de Juana de la Cruz (1481-1532), en Castro, Secundino; Millán, Fernando; Panizo, Pedro (eds.), Umbra, imago, Veritas. Homenaje a los profesores Manuel Gesteira, Eusebio Gil y Antonio Vargas-Machuca, Madrid, Universidad Pontificia de Comillas, 2004, pp. 305-337.

Graña Cid, María del Mar, La feminidad de Jesucristo y sus implicaciones eclesiales en la predicación mística de Juana de la Cruz. (Sobre la Prerreforma y la Querella de las Mujeres en Castilla), "Estudios Eclesiásticos" 84 (2009), pp. 477-513.

Graña Cid, María del Mar, Teólogas de una nueva memoria evangélica en el Renacimiento hispano. Jesucristo como defensor de las mujeres (Isabel de Villena y Juana de la Cruz), en Zarri, Gabriela; Baranda, Nieves, (a cura di), Memoria e Comunità Femminili. Spagna e Italia secc. XV-XVIII, Florencia, University Press - Madrid, UNED, 2011, pp. 49-72.

Guerrau-Jalabert, Anita, L'Arbre de Jesé et l'ordre chrétien de la parenté, en Iogna-Prat, Dominique; Palazzo Éric; Russo, Daniel et al. (eds.), Marie. Le culte de la Vierge dans la Société Médiévale, París, Beauchesne, 1996, pp. 137-170.

Gerrero Lovillo, José, Sobre el origen indio del arbol de Jesé, "Archivo Español de Arte" 17 (1944), pp. 330-333.

Klapisch-Zuber, Christiane, L'Ombre des ancêtres. Essai sur l'imaginaire médiéval de la parenté, París, Fayard, 2000.

Légitimation et lignage en péninsule Ibérique au Moyen Âge, "e-Spania" [en línea] 11 (2011), DOI: 10.4000/e-spania.20366.

López de Salamanca, Juan, Libro de las Historias de Nuestra Señora, Arturo Jiménez Moreno (ed.), San Millán de la Cogolla, CiLengua, 2009.

Mattoso, José, Os livros de Linhagens portugueses e a literature genealógica da Idade Média. A nobreza medieval portuguesa, Lisboa, Estampa, 1981. 
Mexía, Ferrand, Nobiliario vero, Madrid, Ministerio de Educación y Ciencia. Dirección General de Archivos y Bibliotecas. Instituto Bibliográfico Hispánico, 1974.

Muñoz Fernández, Ángela, Santas y beatas neocastellanas. Ambivalencias de la religión y políticas correctoras del poder, Madrid, Dirección General de la Mujer de la Comunidad de Madrid, 1994.

Muñoz Fernández, Ángela, El monacato como espacio de cultura femenina. A propósito de la Inmaculada Concepción de María y la representación de la sexuación femenina, en Nash, Mary; Pascua Sánchez, María José de la; Espigado Tocino, Gloria (eds.), Actas del V Coloquio Internacional de la Asociación Española de Investigación Histórica de las Mujeres: Pautas Históricas de Sociabilidad Femenina. Rituales y modelos de representación, Cádiz, Servicio de Publicaciones de la Universidad de Cádiz, 1999, pp. 71-100.

Muñoz Fernández, Ángela, La reescritura femenina de los símbolos religiosos: Santa Ana en autoras hispanas de los siglos XV al XVII, en Pérez Cantó, Pilar; Postigo Castellanos, Elena (eds.), Autoras y protagonistas. Primer Encuentro entre el Instituto Universitario de Estudios de la Mujer y la New York University en Madrid, Madrid, Ediciones de la Universidad Autónoma de Madrid, 2000, pp.137-154.

Muñoz Fernández, Ángela, Mujeres y religión en las sociedades ibéricas. Voces y espacios, ecos y confines (ss. XIII-XVI), en Historia de las mujeres en España e Iberoamérica, vol. I, Madrid, Cátedra, 2005, pp. 715-742.

Muñoz Fernández, Ángela, Santidad Femenina, controversia judeoconversa y Reforma (Sobre las agencias culturales en el reinado de los Reyes Católicos), en Boucheron, Patrick; Ruiz Gómez, Francisco (coord.), Modelos culturales y pautas sociales al final de la Edad Media: Estado, Iglesia y Sociedad, Cuenca, Servicio de Publicaciones de la Universidad de Castilla-La Mancha - Madrid, Casa de Velázquez, 2009, pp. 387-428.

Muñoz Fernández, Ángela, Las parteras. Imaginario religioso, realidad social y funcionalidades políticas, en Cid, Rosa (ed.), Maternidades. Discursos y prácticas históricas. XIV Coloquio Internacional de la AEIHM, 6-8 de noviembre de 2008, Madrid, Al-Mudayna, 2010, pp. 173-284.

Muñoz Fernández, Ángela, Memorias del Coro: Constanza de Castilla y las políticas del recuerdo, en Zarri, Gabriella; Baranda Leturio, Nieves (a cura di), Memoria e Cominitá femminili. Spagna e Italia, secc. XV-XVII, Florencia, University Press - Madrid, UNED, 2011, pp. 27-48. 
Muñoz Fernández, Ángela, María y el marco teológico de la Querella de las Mujeres (Interferencias y transferencias con los debates culturales de la Castilla siglo XV), "Arenal” 20/2 (2013), pp. 235-262.

Muñoz Fernández, Ángela, La nuova legge come ambito di eguaglianza tra $i$ sessi in Juana de la Cruz (1481-1534), en Giordano, Maria Laura; Valerio, Adriana (eds.), Donne e Bibbia nella crisi dell'Europa cattolica (secoli XVI-XVII), Trapani, Il Pozzo di Giacobbe, 2014, pp. 83-99.

Muñoz Fernández, Ángela, Las cuestiones de Minerva. Problemata en torno a la acción femenina en los debates culturales del siglo XV, en García Herrero, María del Carmen; Pérez Galán, Cristina (eds.), Mujeres de la Edad Media. Actividades políticas, socioeconómicas y culturales, Zaragoza, Institución Fernando el Católico, en prensa.

Netanyahu, Benzión, Los orígenes de la Inquisición, Barcelona, Crítica, 1999 ( $1^{\text {a }}$ ed. inglesa, 1995).

Nirenberg, David, Mass Conversion and Genealogical Mentalities: Jews and Christians in Fifteenth-Century Spain, "Past and Present" 174/1 (2002), pp. 3-41.

Nixon, Virginia, Mary's Mother. Saint Anne in Late Medieval Europe, Pennsylvania, The Pennsylvania State University Press, 2004,

Oropesa, Alonso de, Luz para conocimiento de los gentiles, Luis A. Díaz y Díaz (ed.), Madrid, FUE-UPSA, 1979.

Pastore, Estefanía, Una herejía española. Conversos, Alumbrados e Inquisición (1449-1559), Madrid, Marcial Pons, 2010.

Pereda Espeso, Felipe, Mencía de Mendoza, mujer del I Condestable de Castilla: el significado del patronazgo femenino en la Castilla del siglo $X V$, en Patronos y coleccionistas: los condestables de Castilla y el arte (siglos XV-XVII, Valladolid, Secretariado de Publicaciones e Intercambio Científico de la Universidad de Valladolid, 2005, pp. 9-119.

Pereda Espeso, Felipe, La Puerta de los Leones de la catedral de Toledo: una interpretación en clave litúrgica y funeraria, en Borngässer, Barbara; Karge, Henrik; Klein, Bruno (eds.), Grabkunst und Sepulkralkultur in Spanien und Portugal / Arte funerario y cultura sepulcral en España y Portugal, Frankfurt, Vervuert - Madrid, Iberoamericana, 2006, pp. 155-190.

Pérez Higuera, Teresa, El foco toledano y su entorno, en Actas del Congreso Internacional sobre Gil de Siloé y la Escultura de su época, Burgos, Institución Fernán González - Academia Burgense de Historia y Bellas Artes, 2001, pp. 263-286.

Poza Yagüe, Marta, Santo Domingo de la Calzada-Silos-Compostela. Las representaciones del Árbol de Jesé en el tardorrománico hispano: particularidades iconográficas, "Archivo Español de Arte" 74/295 (2001), pp. 301-313. 
Prieto Lasa, José Ramón, La genealogía de los Haro en el Livro de Linhagens del Conde Barcelós, "Anuario de Estudios Medievales” 43/2 (2013), pp. 833-869.

Robinson, Cynthia, Trees of Love, Trees of Knowledge: Toward the Definition of a Cross-Confessional Current in Late Medieval Iberian Spirituality, "Medieval Encounters" 12/3 (2005), pp. 75-88.

Robinson, Cynthia, The Passion in a Multiconfessional Castile: The Virgin, Christ, Devotions and Images in the Fourteenth and Fifteenth Centuries, Pennsylvania, Pennsylvania State University Press, 2013.

Robles, Juan de, La vida y excelencias e miraglos de Santa Ana y de la Gloriosa Nuestra Señora Santa María, Sevilla, 1511.

Rodríguez de la Cámara, Juan, Obras, Madrid, Sociedad de Bibliófilos Españoles, 1884.

Rodríguez Velasco, Jesús, El debate sobre la caballería en el siglo XV. La tratadística caballeresca en su marco europeo, Valladolid, Junta de Castilla y León. Consejería de Educación y Cultura, 1996.

Rodríguez Velasco, Jesús D., Ciudadanía, soberanía monárquica y caballería. Poética del orden de la caballería, Madrid, Akal, 2009.

Ruiz-Gálvez Priego, Estrella, Religión de la mère, religión des mères. Sainte Anne éducatrice: Les images de la mère selon l'iconographie de Sainte Anne, XVe-XVIIe siècle, en Delumeau, Jean (ed.), Les femmes et la transmisión de la foi, Paris, Editions du Cerf, 1992, pp. 123-155.

Ruiz-Gálvez Priego, Estrella, Maternité, Sainteté et Modèle Social. Ste Anne, du symbole au modèle social. Iconographie et evolution d'un theme (XVe-XVIIe siècles, en Mohamed Kerrou (ed.), L'Autorité des saintes. Perspectives Historiques et socio-anthropoloquiques en Méditerranée occidentale, Paris, Editions Recherche sus les civilisations, 1998, pp. 55-56.

Ruiz Morell, Olga, El Levirato: del mundo bíblico al judaísmo clásico, "Miscelánea de Estudios Árabes y Hebreos. Sección hebreo” 57 (2008), pp. 213-245.

Sainz Rodríguez, Pedro, La siembra mística del Cardenal Cisneros y las reformas de la Iglesia, Madrid, Fundación Universitaria Española Universidad Pontificia de Salamanca, 1979.

Sanz, M. Jesús, Algunas representaciones del Árbol de Jessé, durante el siglo XVI en Sevilla y su antiguo reino, "Cuadernos de Arte e Iconografía" 2/4 (1989), pp. 120-127.

Sicroff, Albert A., Los estatutos de limpieza de sangre. Controversias entre los siglos XV y XVII, Madrid, Taurus, 1985.

Simmons Greenhill, Eleanor, The Child in the Tree. A Study of the Cosmological Tree in Christian Tradition, "Traditio" 10 (1954), pp. 323-371. 
Spiegel, Gabrielle, Genealogy: Form and Function in Medieval Historical Narrative, "History and Theory" 22 (1983), pp. 43-53.

Surtz, Ronald E., The Guitar of God, Gender, Power and Authority in the Visionary World of Mother Juana de la Cruz (1481-1534), Philadelphia, University of Pennsylvania Press, 1990.

Surtz, Ronald E., Writing Women in Late Medieval and Early Modern Spain. The Mothers of Saint Teresa of Avila, Philadelphia, University of Pennsylvania Press, 1995.

Surtz, Ronald E, The Privileging of the Feminine in the Trinity Sermon of Mother Juana de la Cruz, en Eich, Jennifer L.; Guillespie, Jeanne I. (eds.), Women's Voices and the Politics of Spanish Empire, Tulane, University Press of the South, 2009, pp. 87-107.

Teijeira Pablos, María Dolores, La iconografía del árbol de Jesé en la Catedral de León, "Boletín del Museo e Instituto Camón Aznar" 54 (1993), pp. 69-86.

Valera, Diego de, Espejo de verdadera nobleza, en Prosistas castellanos del siglo XV, Mario Penna (ed.), Madrid, Biblioteca de Autores Españoles, 1959, pp. 90-116.

Valera, Diego de, Tratado de defensa de las virtuosas mujeres, Madrid, El Archipiélago, 1983.

Valdez del Álamo, Elisabeth, Visiones y profecía: el árbol de Jesé en el claustro de Silos, en El Románico en Silos. IX Centenario de la Consagración de la Iglesia y el Claustro, Silos, Abadía, 1990, pp. 173-202.

Valle, Carlos del (ed.), Tratado contra los madianitas e ismaelitas de Juan de Torquemada (Contra la discriminación conversa), Madrid, Aben Ezra Ediciones, 2002.

Vargas, Ana, La Querella de las Mujeres en los reinos hispánicos: los textos en defensa de las mujeres (siglo XV), Madrid, UCM, 2011 (tesis doctoral).

Vauchez, André, La Sainteté en Occident aux derniers siècles du Moyen Age. D'après les procès de canonisation et les documents hagiographiques, Roma, École Française de Rome, 1981.

Ventura Avanzinelli, Milka, Sterilità e fecundità delle donne bibliche, "Storia delle donne" 1 (2005), pp. 75-88.

Verdín-Díaz, Guillermo, Alonso de Cartagena y el Defensorium Unitatis Christianae, Oviedo, Universidad de Oviedo, 1992.

Watson, Arthur, The Early Iconography of the Tree of Jesse, Oxford, Oxford University Press, 1934.

Zarri, Gabriella, Le sante vive. Profezie di corte e devozione femminile tra '400 e '500, Turín, Rosenberg\&Sellier, 1990.

Fecha de recepción del artículo: diciembre 2013

Fecha deaceptación y versión definitiva: abril 2014

ANUARIO DE Estudios MEDIEVALES, 44/1, enero-junio 2014, pp. 433-473

ISSN 0066-5061, doi:10.3989/aem.2014.44.1.14 